\title{
FEDERALISM AND LEGAL PROCESS: HISTORICAL AND CONTEMPORARY ANALYSIS OF THE AMERICAN SYSTEM
}

\author{
HARRY N. SCHEIBER
}

\begin{abstract}
Whether federalism is more than a legal fiction is a question that generates considerable controversy among scholars in law and the social sciences. Historians of nineteenth-century American federalism have differed about the workings of the federal system in the era characterized as "dual federalism." This article provides an analysis of these controversies and offers a theoretical position on the problem of real power under federalism. The historical literature, it is argued, provides legal scholars and social scientists with abundant data on the reach, diversity, and effects of governmental action in the different historical epochs of American federalism. The relationship of federalism in the United States to political freedom, governmental performance and efficiency, and the formation of public policy all receive attention.
\end{abstract}

\section{INTRODUCTION}

The analysis of centralized and decentralized power in federal systems of government has long been a major theme in social research and in historical studies of law. Until fairly recently, however, such research focused mainly upon formal constitutional analysis and institutional development. One work in particular, Federalism: Mature and Emergent (Macmahon, 1955), served as a summarium of the traditional style yet also introduced major new lines of analysis that have continued to influence research today. In this latter category were articles by Herbert Wechsler, David Truman, Adolph A. Berle Jr., and Henry M. Hart Jr., which successfully broke the older mold of legal-institutional analysis to introduce considerations such as the behavioral impact of parties organized by states and representing "state interests" in

The author is grateful to Richard Abel for instructive criticism and suggestions at several stages of the work, and to Michael Parrish, Samuel Beer, Harold Hyman, and Lawrence M. Friedman, all of whom generously shared ideas but bear no responsibility for what is said here.

LAW \& SOCIETY REVIEW, Volume 14, Number 3 (Spring 1980) 
Congress, the extent of compliance by the lower federal courts and state courts with Supreme Court decisions, and the interplay between "pluralism" as a political mode and economic structures, lawmaking processes, and constitutional change. The more innovative essays in Macmahon's collection thus advanced the premise that federalism must be studied in the context of dynamic political, economic, and social systems.

Today, a quarter century later, it can be said with some confidence, if also with regret, that the study of federalism is in considerable disarray-whether despite or because of the shift away from formalism. Few concepts in legal or social research, for example, have been made the subjects of books with titles as disarming as Federalism: Infinite Variety in Theory and Practice (Earle, 1968). Of course, an analytic category susceptible to "infinite [or indefinite] variety," whether of theory or application, is a category without coherent meaning. Similarly, one confronts with some dismay the review essay by a political scientist, long viewed as a doyen of the study of federalism, to which he gives the title "Six Books in Search of a Subject, or Does Federalism Exist and Does It Matter?" (Riker, 1969). "Almost no ordinary citizens of the United States, or, indeed of any other federal republic," writes Riker, "concern themselves often or seriously about federalism," yet an academic literature has been written on the premise that federalism does matter-an assumption that reflects and inspires "the misdirection of so much scholarly effort, including, incidentally, my own. .." (Ibid.: 135, 145). Federalism, he concludes, is a legal fiction, a structure that makes little real difference in the way a polity is governed, and for purposes of social research we ought henceforth to regard it as such (Ibid.: 145-56). Whereas Truman and Wechsler before him (Macmahon, 1955) treated the party system and the political process as mechanisms that reinforced the anticentralist functions of American federalism, Riker now asserts that only parties and other such "real" political actors matter. At best, he offers only a grudging acceptance of the most spectral kind of federalism: "Since some lawyers appear to believe in it, we must, I suppose, concede that it exists" (1969: 136).

This view of federalism as a fiction that lacks historical reality as well as contemporary substance was naturally reinforced by legal realism. Just as the behaviorists, Riker above all, denied the importance of federal organization as an explanatory variable in political analysis, so the legal realists 
bequeathed to later social and legal analysts a view of the constitutional system, legal doctrine, and (at least by implication) the federal structure that downgraded the importance of ideas and institutions such as federalism. Like the later behaviorists, the legal realists sought to understand the "real forces" that lay behind institutional forms, doctrines, and attachments to quaint eighteenth-century structures. Historical analysis of constitutional origins, influenced by the skepticism and iconoclasm of scholars like Beard (1913) and his modern followers (e.g., M. Jensen, 1950), reinforced the legal realist position on federalism. Similarly, a realist reading of the Supreme Court's development of major doctrines-even before the notorious reification of "liberty of contract" by a conservative Court-leads easily to a view such as Levinson's critique of the Chase Court: "most of the so-called great debates of American constitutional law were based less on theory than on political or economic exigencies. Federalism was a value to be attacked or cherished depending on the ends of the debaters" (1974: 480). That the Supreme Court is "purposive, teleological, immersed in the travail of society" (Miller and Scheflin, 1967: 535) and that the doctrines and actual structures of federalism are shaped by the same forces that exert profound influence on the lawmakers, are axiomatic in realist analysis (see R. Gordon, 1975). However, unlike Riker, who was scarcely willing to grant federalism any importance in real life, the realists have tended to view federalism-or at least formalistic attachment to its legal principles-as a palpable social evil.

At the high tide of New Deal enthusiasm for a new political economy and in the face of an intransigent Supreme Court, Karl Llewelyn thus wrote that the federal system was a reality but that "the actual lines of distribution [of power] are inane" (1934: 38). Far from dismissing federalism as an insignificant variable of no importance in explaining political or socioeconomic change, Llewelyn viewed traditional constitutionalism as capable of "forcing growth out of certain institutional channels ... [or] into certain channels; and sometimes it checks growth for a time . . . or even chokes it off entirely" (Llewelyn, 1934: 14).

At the other extreme is the attachment to traditional normative values believed to be served by federalism, perhaps best exemplified in the recent literature by the work of Philip Kurland. Kurland has conceded that "federalism as a viable constitutional principle . . . is moribund if it is not dead," but 
he views the principal question for further analysis as: "Why did federalism succumb?" (1968: 6). Kurland contends that American government once conformed to the definition of American federalism in K.C. Wheare's classic study (1963): though the Constitution might draw only a vague line between the "allotted sphere" of the central government and that of the states, "once granted that a government is acting within its allotted sphere, that government is not subordinate to any other. ... The principle of organization upon which the American association is based is that of the division of powers between distinct and co-ordinate governments" (Wheare, quoted in Kurland, 1978: 156). That era is now over, terminated most decisively by the New Deal (with the accompanying triumph of the attitudes and ideas championed by realists such as Llewelyn).

Kurland maintains that the nation has lost something important, indeed fundamental, with the demise of federalism. While it worked in accord with the original design of 1787, which Wheare has properly read, the federal character of the American polity and its constitutional underpinnings served to maintain limitations upon government and to guarantee individual liberties. Those who admire the achievements of the New Deal see traditional federalism as "the lethal weapon" used by a Supreme Court hell-bent on stopping the movement toward welfare-state and regulatory-state reforms (Mason, 1969: 391). Analysts such as Kurland contend, on the contrary, that the tenets of the old federalism were incorporated into constitutional doctrine "not as a matter of doctrinaire localism but as a promoter of democracy" (San Diego Building Trades Council v. Garmon, 359 U.S. 236, 243, 1959, Frankfurter, J.). Citing the vast increase in executive authority after 1933 (the Imperial Presidency) as well as decisions (like those on reapportionment) that bespeak Supreme Court activism at the expense of traditional state prerogatives, Kurland concludes: "It is no longer true that there are any substantial areas of government that cannot be exercised by the national government or any that can be exercised only by the states" (1978: 156). The "inanities" once condemned by Llewelyn have been thoroughly rooted out.

American federalism has been the subject of numerous death notices penned by distinguished commentators, not all of them ideologically aligned with Professor Kurland. Thus Corwin (1950) declared that the classic "dual federalism" (conforming to Wheare's definition cited earlier) had been 
"overwhelmed" and largely superseded by "cooperative federalism." The newly fashioned system was the legacy of the New Deal; it involved the extensive use of intergovernmental grant-in-aid programs, but its principal feature was centralization of power in the national government. More recently, Michael Reagan has declared flatly that "federalismold style-is dead," no longer viable in serving to demarcate central-government and state-government responsibilities (1972: 3). He does not, however, mourn the passing of a doctrine that limited the extension of centralized power: "Federalism-new style-is alive and well and living in the United States. Its name is intergovernmental relations, . . . a political and pragmatic concept stressing the actual interdependence and sharing of functions between Washington and the states" (Ibid.).

If federalism is susceptible to "infinite variety in theory and practice" (Earle, 1968), imagine the possibilities for this substitute concept, intergovernmental relations! Will anyone mourn the "demise of intergovernmental relations" one day in the distant future? Will future analysts be able to look back and reckon the social costs and gains attributable to, or the constitutional values implicit in, intergovernmental relations? If one accepts William Anderson's definition (1960: 3) of IGR as "an important body of activities or interactions occurring between governmental units of all types and levels within the federal system," would not an exclusive attention to IGR impoverish scholarly analysis of American federalism?1

I hasten to say that there is a useful and growing literature on such aspects of intergovernmental relations as fiscal relationships among governmental units and revenue sharing; the behavior of officialdom in an increasingly complex, technocratic universe of governmental agencies; and the problem of where and how discretion is exercised in the administrative framework of modern cooperative federalism.

1 The best of the newer writings on IGR, it should be stressed, assert that use of the term "federalism" remains appropriate for "legal-juridical" matters (Reagan, 1972: 24-25); moreover, even a shifting of analytic focus to the working relationships among governments in a system dominated (at least administratively) by "sharing" does not preclude recognition and informed discussion of historical problems, as in Wright (1978: 39-66).

In fact, one is struck by the attention some contemporary analysts lavish on the task of discrediting "federalism" as a conceptual focus because of its vagueness or ambiguities when these same analysts then go on to treat at length problems that have long been dealt with quite satisfactorily under that conceptual designation. A wonderfully idiosyncratic approach to the semantic and analytic perplexities of such modern scholarship may be found in the first major work in two decades dedicated to the theory of federalism (Davis, 1978). 
But these are not the only interesting and important questions relating to legal process and the federal system, historical and contemporary. The fascination of political scientists with IGR is partly the product of that discipline's general preoccupation with matters technocratic and administrative, especially in the 1960 s, before the rediscovery of ideology forced upon the discipline by real-world events and expedited by the disillusionment with Establishment social science inspired by the Vietnam disasters. But this narrowing concern with IGR is also a product of a longer-run phenomenon rooted in the twentieth-century history of the discipline and related functionally to legal realism: the pragmatism that for so long was a dominant strain in many areas of the discipline (Wickwar, 1970: 70-74). As will be seen in a later section of this paper (pp. 675ff., infra), the pragmatic view of modern federalism, or rather IGR, has been reinforced by the nicely congruous but utterly spurious notion that dual federalism is only a myth, that historically the American system has always worked pragmatically, without serious regard to the tenets of constitutionalism that prescribe distinct coordinate governments.

Thus we have before us the rather sorry prospect of federalism condemned as a legal fiction, of no explanatory value in social or political analysis; federalism as a villain; federalism as a corpse; and, finally, federalism as merely the now-departed precursor (whether once a reality or always a myth) of modern IGR.

Happily-at least for those of us who continue to deal with federalism, past and present, as a topic expressive of important realities in law, political structure, and legal process-some rather startling recent developments have revitalized traditional issues associated with federalism, pushing them into the forefront of both public and scholarly debate.

Moreover, these movements in the arenas of both policy and law (to be examined below) have converged with new research on the history of law and policy that has a direct bearing on the newly reemergent questions of contemporary federalism. Important normative questions are raised by the latter scholarship, most notably by the work of Willard Hurst. The new legal history has also given us a growing base of empirical data on federalism as a working system in the nineteenth century and more recently. The data base is especially enriched by intensive studies of public policy in single states (see Scheiber, 1972: 135-51) and by monographic 
studies of such matters as diversity jurisdiction, nuisance law, and eminent domain law in the nineteenth century, and civil rights and civil liberties in both the nineteenth and twentieth centuries. And, surprisingly, the Supreme Court has now returned to celebrating "our federalism" in terms that have seldom been heard in the last four decades.

All these developments-in politics, law, and scholarshipsuggest the appropriateness of considering how emergent historical knowledge may contribute profitably to an appraisal of the normative and empirical studies of contemporary federalism. This paper will deal with some of the major areas that link historical study of federalism and legal process with contemporary analysis of comparable phenomena.

\section{CONTEMPORARY FEDERALISM: CENTRALIZED, "NONCENTRALIZED," OR WHAT?}

Even if we eschew Riker's proposal that the concept of federalism be scrapped except to illustrate the uses of myth or symbol, we are still left with the vagaries of contemporary definition. Thus, Deil Wright, in his major new work on intergovernmental relations, has complained that an "inventyour-own-federalism game" has muddied the scholarly waters and also politicized the term:

[A] host of value-laden adjectives have been attached to the leading edge of a historic and significant concept and have, from whatever motives, blunted the term's meaning and thus limited its analytic utility. . . . At least thirty-four different "types" of federalism have been recorded. Clearly, federalism is a much-used and much-abused term. [1978: 19]

Wright has, in fact, underestimated the ingenuity of politicians and academics as phrase makers or obscurantists. S. Rufus Davis, an Australian student of federalism, compiled a list of 44 types of federalism currently in use by scholars (1978: 204). ${ }^{2}$ This adjectival fecundity leads Davis to an even more profound despair.

There has rarely been a time in the history of the subject when it has been in a more depressing and uncertain condition than it is now. And this is not because we know less about the facts of federal life; on the contrary, there has never been a time when so much has been known about the subject, nor indeed [when there has been a greater] awareness of what more there is to know. [1978: 204]

2 Dual, orthodox, classic, polis, traditional, cooperative, bargaining, integrated, interdependent, creative, new, permissive, functional, pragmatic, organic, pluralistic, monarchic, perfect, imperfect, direct, private, picket fence, coercive, competitive, centralized, decentralist, peripheralized, fused, corporate, national, social, oligarchic, unitary, constitutional, international, military, political, monistic, polar, total, partial, contract, feudal-functional, incipient. 
Although the sources and motives of such widely acknowledged confusion are numerous, one factor contributing to the confusion deserves special mention: the notion that the present federal system (including IGR) is neither "centralized" nor "decentralized" but rather "noncentralized." The principal champion of this view is Daniel Elazar, who contends that the federal system of the United States is a nonhierarchical arrangement in which "power is so diffused that it cannot be legitimately centralized or concentrated without breaking the structure and spirit of the constitution," as a matter of either constitutional or political legitimacy (1975: 23$).^{3}$

There are two major sources for this view. ${ }^{4}$ One is the wellknown contention of the late Morton Grodzins that the dominant feature of contemporary federalism is not a division of power and responsibilities between the central government and the states but a "sharing" between them, indeed a particular style of sharing characterized by "mild chaos" (1966: $316,11-12)$. In his most-quoted phrase, Grodzins asserts that the traditional "layer-cake" metaphor ${ }^{5}$ for American federalism as a three-level system (national, state, and local governments)

3 Elazar is the author of several major works on federalism, with whose premises and findings I strongly disagree; see, e.g., Scheiber (1966).

4 Readers interested in pursuing this semantic issue and its treatment by Elazar and Grodzins in particular should consult Elazar's report (Grodzins, 1966: 316 note) of his unsuccessful efforts to persuade his mentor Grodzins to substitute "noncentralized" for "decentralized."

Quite correctly, some scholars have insisted upon distinguishing two meanings of "decentralization": devolution of functions by a central authority on subordinate governments (as has been done, for instance, in Great Britain), and diffusion of real power as a matter of constitutional design and the legitimate rights of the lower-level governments. Diamond, criticizing Grodzins, insists that formal federalism - the constitutional imperative-is a real force in diffusion of power (1964: 72-81). He quotes Schattschneider: "the Constitution is the river bed, the firm land whose contour shapes the stream" of decentralized parties (Ibid.: 81). See also my discussion of "real power" and "formal authority," infra, pp. 692-95. In the present work, "decentralization" is used to denote diffusion of both formal constitutional authority and real governmental decision-making powers.

Devolution in Great Britain is not of concern here; for analysis of the 1973 Royal Commission report on the Constitution and the 1974 report on devolution, as well as an introduction to the critical literature, see G. W. Jones (1974: 182-93).

5 This ingenious phrase actually seems to have entered the vocabulary of modern political science and political rhetoric in 1952, when Joseph E. McLean employed it in a pamphlet:

Most of us think of our federal system as having three layers of government ... with each level assigned definite functions and responsibilities.... [so] that a specific service or function generally belongs exclusively to one layer of government. . . . Most of us fail to realize that this layercake is much more like a marble cake. There are many combined activities-administrative, financial, and politicalwhich blend throughout the cake and ignore the layers. .... Almost any public problem you can mention today involves all of the so called 'layers' of government. [Quoted in T.J. Graves, 1974: 46] 
is a fallacy as a description of both historical and contemporary practice.

In fact, the American system of government as it operates is not a layer cake at all. It is not three layers. . . Operationally, it is a marble cake, or what the British call a rainbow cake. No important activity of government in the United States is the exclusive province of one of the levels, not even what may be regarded as the most national of functions, such as foreign relations. ... [ [Ibid.: 8]

The multitude of governments does not mask any simplicity of activity. There is no neat division of functions among them. If one looks closely, it appears that virtually all governments are involved in virtually all functions. [Ibid.: 4]

The second, closely related, source of the view that modern-day federalism is "noncentralized" derives from work such as that by Truman and Wechsler (Macmahon, 1955) exploring the relationship of the American party system in the 1950 s and early $1960 \mathrm{~s}$ to federalism. The main conclusion of this research was that the essentially "federalized" nature of the major parties, together with a constitutional structure that affords state-based parties great influence over Congressional decisions, serves to ensure the diffusion of real political power in the system (Grodzins, 1966: 254ff.). ${ }^{6}$

From this starting point, Elazar goes on to maintain that the states function as "civil societies" that can mobilize power within the system "to resist 'encroachments' or to gain benefits from the outside" (1966: 55). This view asserts the "integrity" of the states in the sharing "partnership" with the national government: this "noncentralized system functions to a great extent through bargaining and negotiation" rather than through hierarchical command relationships (Ibid.: 203). This benign perception of the modern federal system and this faith that "sharing" represents authentic diffusion of real power are the intellectual descendants of theories about political parties (by Truman and others) and about the nonideological character of alleged consensual "pluralism" (dominant in the writings of political scientists like Truman and Grodzins and reinforced by the work of historians like Daniel Boorstin) that had a timebound plausibility in the 1950s and early 1960s.?

6 Riker (1964: 129) carried this point even further, identifying party organization as the single most important variable in determining the centralization of power: "The federal relationship is centralized according to the degree to which the parties organized to operate the central government control the parties organized to operate the constituent governments." Riker asserts that the party system is "the main variable intervening between the background social conditions and the specific nature of the federal bargain" (Ibid.).

7 There is not room here to deal in extenso with the relationship between the concept of a historical "consensus," the faith in pluralism, the attenuated concern for principled issues of federalism, and the benign view of how well 
The aggrandizement of power by the national government, especially the executive branch, during the Nixon "New Federalism" years-despite the rhetoric and posturing through which the administration sought to claim it was actually engaged in decentralization-shook the faith of many analysts in the model of contemporary federalism as "noncentralized." Even Elazar warned that Nixon's legislative program was producing "more centralization whether needed or not, federal preemption of formerly cooperative activities whether needed or not, federal administrative dominance whether needed or not" (1972: 152). Interestingly, Elazar stated that these tendencies dated to the Johnson "Great Society" even though in those days Elazar was wholly persuaded that the system was benignly noncentralized. His conversion to the view that the Johnson and Nixon organizational innovations and programs were producing a "hierarchical organization of power whereby the federal government monopolizes policymaking and uses the state and localities as its relatively passive agents to carry out its programs" was rather unexpected (Ibid.). $\mathrm{He}$ now appears to accept my view (1966) that the Grodzins-Elazar "noncentralization" model is inaccurate precisely because "sharing" is not evidence of decentralization or diffusion of real power (see generally Friedrich, 1968: 8 and n.10).

"the American system" was working as a model of democracy (indeed, the uncritical enthusiasm for domestic institutions) in the prevailing ideology of American political scientists in the 1950s and early 1960s. That Daniel Bell and others were writing a premature epitaph in asserting "the end of ideology" became startlingly clear with the polarization of American politics in the Vietnam years. Instead, Establishment political scientists abandoned all pretense of engaging in "value-free scientific analysis" and disclosed the manifest bankruptcy of older premises about consensus, historical and contemporary. Formal recognition that a new academic day was dawning came with David Easton's 1969 presidential address to the American Political Science Association, in which he confessed that the discipline must begin to examine its "normative presuppostions" and its "operating values" instead of perpetuating "the myth that research can be value-free or neutral" (1971: 338). On the issue of consensus, cf. Higham (1970). Attacked by Holt (1974: 623-24) and Horwitz (1977: xiv) for his attachment to the notion of consensus in the nineteenth-century United States, Hurst offers mature reflections in his latest major work (1977: 226); my own caveats about his argument that a consensual Volksgeist characterized the Jacksonian era and most of the 19th century are contained in Scheiber (1970). See also Diamond (1979).

Orlans commented on the passing of the earlier faith in "a great progressive democratic consensus" based on the idea of pluralism and shifting political coalitions: "But now, in 1968, the happy pluralistic consensus that once produced a kind of automatic, Victorian political progress has turned into a bog, an unmappable, unworkable nonsystem of messages that enter and never emerge. The government has become a vast Kafkaesque bureaucracy ..." (1971: 272). Despite the harshness of the language, this was but a peculiarly bitter variant of indictments increasingly heard even among the pragmatic liberal, or technocratic, reformers in Congress by the early $1970 \mathrm{~s}$ (see Scheiber, 1978a: 665 and n.214). 
The conceptual waters are not cleared much by the contribution of Richard Leach, long one of the leading students of federal-state relations, who has argued that "shared functions, without regard to neat allocations of responsibility, is thus the core of American governmental operations and of the theory of federalism as well" (1970: 15; italics added). Precisely whose theory of federalism derogates the importance of such allocations or places "sharing" at the "core" is left unstated.

Against these assessments of contemporary federalism are set the views of other scholars who contend that the system is now highly centralized, as far as real power is concerned. I have already mentioned my own view that dramatic centralization of power occurred in the 1960s and 1970s but actually represented an accelerated shift in the locus of power from the states to Washington beginning in $1933(1966,1978)$. Martin Landau wrote in 1969 that "the United States has evolved into a highly centralized, integrated community. . . . It no longer possesses federal characteristics. .." (1969: 137). Riker averred in the mid-sixties that "the central government has continually aggrandized itself at the expense of the states," both through expanding constitutional claims and through the proliferation of the national governmental responsibilities, by which they "have come to cover more and more of the whole field of governing" (1965: 302). Table 1 shows Riker's estimates of how specific substantive governmental functions were progressively centralized.

More recently, Abraham has found it "patently obvious" that despite revenue sharing and Nixon-era rhetoric, the federal system has become ever more centralized:

The long apparent trend toward centralization of federal power at the seat and in the hands of the national government is, at once, an axiom of modern American federalism and irreversible-absent drastic and dramatic constitutional changes, which simply will not take place. [1976: 94]

Lowi (1969) used to argue that there was so much fragmentation and complexity in both the political and the economic systems that lack of centralized control of policy was a hallmark of federal program administration. Now, however, he has concluded that "a large, positive, interventionist, national state is finally and forever the central feature of the American system" (1978: 26). Even Reagan, who notes with satisfaction the "death" of traditional federalism, finding pragmatic "intergovernmental relations" more congruent with modern needs, has coined the term Permissive Federalism (Lieber, 1975, terms it Lip-Service Federalism!) to describe 
TABLE 1

Estimates of Degree of

Centralization in the United States, By SUBSTANTIVE FUnCTIONS: $1790,1850,1910,1964$

\begin{tabular}{lcccc}
\hline \hline Functions & ca. 1790 & ca. 1850 & ca. 1910 & ca. 1964 \\
\hline External affairs & 4 & 1 & 1 & 1 \\
Public safety & 5 & 4 & 4 & 4 \\
Property rights & 5 & 5 & 4 & 4 \\
Civic rights & 5 & 5 & 5 & 3 \\
Morality & 5 & 5 & 5 & 5 \\
Patriotism & 3 & 3 & 3 & 3 \\
Money and credit & 3 & 4 & 3 & 1 \\
Transport and communication & 4 & 4 & 2 & 2 \\
Utilities & 5 & 5 & 5 & 4 \\
Production and distribution & 5 & 5 & 4 & 2 \\
Economic development & 3 & 4 & 3 & 2 \\
Resources & $-a$ & $-a$ & 2 & 2 \\
Education & - & 5 & 5 & 4 \\
Indigency & 5 & 5 & 5 & 2 \\
Recreation & - & 4 & 4 & 3 \\
Health & - & - & 4 & 3 \\
Knowledge & 1 & 1 & 1 & 2 \\
\hline
\end{tabular}

Legend: 1. Functions performed exclusively or almost exclusively by the federal government.

2. Functions performed predominantly by the federal government, although the state governments play a significant secondary role.

3. Functions performed by federal and state governments in about equal proportions.

4. Functions performed predominantly by the state governments, although the federal government plays a secondary role.

5. Functions performed exclusively or almost exclusively by the state governments.

-The functions were not recognized to exist at the time.

a Editor's Note: Apparently land policy is not included in this category.

Source: Riker (1964): 82-83.

contemporary reality: in the last analysis, states and their constituent local governments share real decision-making power only with the "permission and the permissiveness of the federal government" (Reagan, 1972: 163).

One scarcely needs to be reminded that from the 1930 s to the Eisenhower years, analyses of federalism (or IGR, or both) concluding that "centralization" of power was occurring tended to be a leading theme (or alarum) mainly in conservative circles. $^{8}$ Yet, as the foregoing summary indicates, liberal

8 Eisenhower himself, of course, frequently reverted to small-government and states-rights rhetoric (albeit of a far milder sort than that of politicians to his right) on domestic policy issues. The assertion of "state sovereignty" arguments by opponents of expanded welfare and regulatory programs was the direct continuation of anti-New Deal criticism in the thirties (Sundquist, 1968: 416-22.) In the 1950s, however, activism of the Warren Court on school desegregation, followed a decade later by its position on reapportionment, 
analysts have come to share that view, and so, too, have radicals of the left. The indictment of centralized power and the call to restore local community control-a critical school much influenced by Saul Alinsky (Harper's Magazine, 1965) and later by the popular writings of Charles Reich (1970)found effective expression, for example, in a widely read essay by Goodwin (1967: 120), who candidly acknowledges that "conservatives have something to teach about the value of institutional arrangements." Monolithic modern government, together with national structures of power in the private sector, had closed off the "alternative outlets" for grievances and for the pursuit of positive goals that local government and private associations had traditionally offered. Now, Goodwin writes, it is vital to reassert the value of diffused political power-not to stifle welfare and regulatory programs, as conservatives urged, but rather to advance them in ways that restore to the individual a sense of mastery over affairs and that are more responsive to real community interests.

Thus we find that older values and traditional federal structures are no longer the exclusive concern of conservative analysts. Both at the center and on the left there is a growing sense that "centralization" tends to maintain its thrust whether Republicans or Democrats control Washington. We may even have come to the point where we can look back on "noncentralization" as a myth that once comforted and obscured-a sort of Tiffany lamp from the political-science thrift shop, now to be enjoyed with the proper sense of nostalgia but not to be relied upon to illuminate modern realities.

\section{THE HISTORICAL DIMENSION}

A judgment of whether centralization has occurred in the federal system necessarily rests upon an historical model, a picture of past conditions and trends, and not merely on an analysis of the present situation. Nearly. all the scholars considered in this study share the premise that the federal system has undergone basic change, though they may differ in their ethical judgments about that change. Thus Corwin, Reagan, Kurland, Lowi, and others view "cooperative federalism" or "centralization" (or both) as deserving of close

elicited anticentralist criticism that represented a heritage from Dixiecrat, anticivil rights progenitors (see Lyons, 1975). Meanwhile, Kurland, Wechsler (1959), and Bickel (1970) opened a different critical front, based on principles of judicial self-restraint and the traditional decentralist values of federalism. 
analysis precisely because they accept the view Corwin popularized, that "dual federalism" was fundamentally transformed in the 1930s, with its corollary that dual federalism once characterized the actual operation of government and not just its formal constitution.

The scholars who championed the "noncentralization" model denied the reality of dual federalism in American history and persuaded many other political scientists, at least for a time. These scholars postulated that the "sharing" allegedly dominant in modern federalism also characterized earlier times. Grodzins advanced this historical argument in an extreme form:

There has in fact never been a time when federal, state, and local functions were separate and distinct. Government does more things in 1963 than it did in 1790 or 1861; but in terms of what government did, there was as much sharing then as today. [1963: 7]

In later writings, Grodzins modified this view, contending that "sharing" dated from 1790 and "continued side by side with the dual pattern" from 1800 to 1913 (1966: 57 and chap. 2).

As so often happens in scholarly discourse, the more extreme expression of an iconoclastic thesis was remembered, while the qualified version was largely forgotten. Thus Leach asserted that it was as much a "fundamental principle of American federalism" in the nineteenth century as it was in the twentieth "that the national government will use its resources in harmony with state and local programs and policies" (1970: 15). An even more strident version of historical continuity came from Martin, who declared that dual federalism was never truly characteristic of the system in operation: "cooperation [not dualism] has characterized the practice of federalism from the early years of the Republic," and intergovernmental sharing "prevailed from the early 1800s" (1965: 37-38). The most recent acceptance of this view, albeit somewhat qualified and cautious, is in a study by Gilbert, who avers that "American federalism has always been a system more of shared than of compartmentalized functions as well as of close public-private collaboration, though interpretations differ in degree" (1976: 121-22).

Despite Gilbert's statement that his is "probably the majority view among scholars" (Ibid.), it is nearly impossible to find any scholarly work on federalism by an historian or legal scholar that accepts the model bequeathed by Grodzins. For to do so, discarding dual federalism as a myth, would be to treat Kurland or Corwin as engaged in misguided mourning for a past that never was. To ask, with Kurland, "Why did 
federalism succumb?" or to view dual federalism, with Corwin, as having once been "a viable constitutional principle," would no longer make sense. If nothing has really changed since 1800 in the distribution of power or the style of government in American federalism, then presumably we must look elsewhere to discover the sources and consequences of change in the government and society of the United States. Whereas Riker contended that federalism is insignificant when compared with parties or other "real" social and political forces, the scholars who accept the Grodzins model reject change in federalism as an historical explanation because they assert that no significant change has occurred.

It is likely that we are trading again in thrift-shop nostalgia. Notwithstanding Gilbert's recent reassertion of the Grodzins model (1976), most contemporary scholarship on federalism seems to have moved to the ground held all along by historians and legal scholars: acceptance of the historical reality of dual federalism. Even some prominent political scientists aligned with the Grodzins-Elazar school on ideological questions seem ready to dissent on issues historical. For example, George C.S. Benson concedes that "obviously something changed between the relatively hit-and-miss, ad hoc cooperation" found in the nineteenth century and the pervasive, more systematic sharing of the 1960s (1965: 3). Similarly, Friedrich (1968: 8) endorsed an alternative view of progreșsive stages of historic federalism that I advanced (1966) in preference to the Grodzins model. ${ }^{9}$ More recently Deil Wright has expressed serious doubt that intergovernmental collaboration "was of major significance," let alone "the dominant fact" of nineteenth century federalism (1974: 7). And in his textbook on IGR, Wright (1978: 39-66) confines himself to discussion of McCulloch v. Maryland (4 Wheaton 316,1819 ) so far as pre-1880s federalism is concerned but clearly recognizes major transformations and centralizing trends in the modern period. That Lowi, Riker, Abraham, and numerous other leading commentators understand the 1930s1970 s as transforming federalism has already been shown. Similarly, James Sundquist $(1969: 1,6)$ views these decades as

9 Friedrich agreed that there have been distinct stages in the history of American federalism, but he faulted my construct for stressing their discontinuity since he found underlying continuity in progressive centralization throughout American history.

Many political scientists, confronted with the completely opposed views reflected in the Grodzins-Elazar model and my own, resort to stating each in turn and then slipping out of the cul de sac with evasive phraseology such as: "Whichever view of the past one holds, there is little question that in the latter part of the 19th century the national government did expand the scope of its activities. . . " (G.J. Gordon, 1978: 123.) 
witnessing a fundamental change in federalism, with the 1960 s bringing "the final burial, perhaps, of traditional doctrines of American federalism that, for a long time, had been dying hard" $(1969: 1,6) .{ }^{10}$

The appropriateness of dual federalism as a description of nineteenth-century government has been reaffirmed in the seminal work of Samuel Beer (1973: 69). A staff study by the Advisory Commission on Intergovernmental Relations (1979: 9) reviews the controversy between Beer and me on the one side and Grodzins and Elazar on the other and concludes that Grodzin's model was "influential" but wrong. (But doubtless this is not the last word.)

Right or wrong, the contention that dual federalism was only a myth forced reexamination of the legal process and federalism in the pre-New Deal period in order to establish variation over time in the developing federal system and to appraise the evidence of "sharing" set forth in great detail, if not faultlessly, by Elazar (1962). Moreover, the controversy over continuity versus discontinuity in the history of American federalism lent additional importance to the new legalhistorical scholarship produced in the 1960s and 1970s. ${ }^{11}$ Did these studies provide evidence that "dual federalism" was an operational reality, or did they suggest that "sharing" and "cooperation" were the prevailing norms? And what did they tell us about the degree of centralization in the nineteenth century?

Three other models of historic federalism have been advanced as alternatives to the assertion that nothing had changed since 1800.12 They require at least brief notice here

10 In his latest major work, Willard Hurst emphasizes the rise of executive power and the increase in overall centralization of policy making within the federal system since 1933, but he also argues that the fragmentation of policymaking responsibility and exemption of regulatory and executive agencies "from effective. scrutiny through the courts" have accompanied these shifts. Thus judicial self-restraint, celebrated as an innovation supportive of liberal reforms, is seen in a new, post-Watergate light (Hurst, 1977: 150-54 et passim).

It is interesting to contrast two contemporaneous articles, one, by C. Peter Magrath (1968: 64), contending that "in fact if not in form we live today under a national, not a federal, constitution" because of Supreme Court decisions since the New Deal, and the other, by Charles Gilbert and David Smith (1968: 139-40), denying "that there has been much centralization."

11 This scholarship has greatly enlarged our knowledge of legal process and policy content in the nineteenth century, as I will show below (pp. 697-703).

12 Very different frameworks are offered elsewhere. Tribe (1978) provides one based on analytical categories that represent overlapping stages of constitutional doctrine, with little attention to the working governmental system except as it is tested in federal courts. Grodzins (1966) offers another that focuses, alternately, on formal doctrine and the prevailing style of intergovernmental relations. Mosher (1968: 54-55 et passim) presents the following scheme based on the "changing concept and practice of ... public 
because they offer legal scholars a frame of reference based on the evidence of governmental practice, against which may be compared models based principally on doctrine (e.g., the new treatise by Tribe, 1978).

\section{A. Beer on Modernization}

Beer (1973) offers a theory of modernization that portrays federalism as a reflection of stages of social change: the degree of economic integration; centralization, in the sense of a shift of decision-making power from the private to the public sector; the emergence of class politics; and finally, the modern development of technocratic-bureaucratic structures in the public sector, which become major political actors in the policymaking process. The central government acquires a "near monopoly of innovation," while at the same time "technocratic coalitions" have become major agents for centralization and other sorts of change: "Bureaucratization matches industrialization as the source of blind development and unintended social costs" (1973: 91). What Beer terms "publicsector politics" in the contemporary era involves not only technocrats but also "topocrats" (state and local officials, organized in intergovernmental lobbies). These developments complicate the nature of representation in the federal system; further centralization and purposive devolution and decentralization result (Beer, 1977: 17-20).

\section{B. Scheiber on Historic Stages}

I have offered a theory of stages in the history of federalism (1978a) that is more concerned with temporal boundaries and watersheds and attends more closely than Beer's theory to changes in law and governmental operations (rather than to models of public administration or modernization).

The first stage, the era of dual federalism and rivalistic state mercantilism, runs from 1789 to 1861 . This is a period

services," i.e. ideology and administrative style: (1) The guardian period, 1789. 1829 (government by gentlemen); (2), the spoils period, 1829-1883 (government by the common man); (3) the reform period, 1883-1906 (government by the good); (4) the scientific management period, 1906-37 (government by the efficient); (5) the management period, $1937-55$ (government by administrators); (6) the scientific period (government by the professional), since 1955. Although Mosher's schema may appear narrowly concerned with administration, it does embrace IGR and the larger system of working government, and in his analysis of the stages, he offers provocative suggestions concerning such problems as pluralism and bureaucratic representation of interests, changing patterns of responsiveness and responsibility, and the like. These themes are also taken up in Beer's more recent 'work (1977). 
when the behavior of the federal system conformed closely to the juridical model of dual federalism. The Supreme Court generally supported dualism in the responsibilities of the central and state governments, and Congress refrained from making innovative policy in many areas formally opened to it by the Court. Moreover, the relatively decentralized character of the economy meant that the states' geographic jurisdiction was congruent with decentralized promotional and regulatory powers.

The second stage, 1861-1890, was one of transitional centralization. Amendment of the Constitution, together with vast expansion of the policy responsibilities of the national government and an increase in the jurisdiction of the federal courts, meant significant centralization of real power. In 1887 Congress undertook national regulation of the railroads, and three years later the Sherman Act marked the beginning of general business regulation. Meanwhile, the Supreme Court's activism was itself a centralizing force, albeit along lines that served to attenuate state initiatives or federal civil rights laws (Tribe, 1978: 5; Scheiber, 1975a: 100-18).

The years 1890-1933 constitute the third stage, accelerating centralization. Successive federal laws advanced national regulation; World War I brought intensive, if temporary, centralization; and the Supreme Court continued to "censor" state legislation with a heavy hand. Modern grants-in-aid originated in this period, although on only a small scale.

A residue of dual federalism from the antebellum era was evident in the area of civil rights, as Southern blacks were left virtually helpless against private coercion, state action, and often terrifying violence; the states continued to have almost exclusive control over labor policy, and they also retained control over such traditional areas as education, family law, and criminal law.

The New Deal inaugurated the fourth stage, which brought the well-known "Constitutional Revolution" and the transformation of the American political economy. Increases in both the extent and intensity of federal regulation, the establishment of regional planning in the Tennessee Valley, federalization of labor policy, the reorganization of agriculture as a managed sector, and expansion of welfare programs all combined with the adoption of Keynesian fiscal policy and contemporary income and estate taxation policy. It was in this broad context of quick and intensive centralization that 
Cooperative Federalism emerged as a style or technique of intergovernmental relations.

The fifth phase is the post-World War II era, in which modern centralized government spawned the Creative Federalism of Johnson and the New Federalism of Nixon and Ford while the Warren Court validated enormous extensions of national power in the fields of race relations, criminal justice, and structural reform. Many areas of policy for which state and local government were responsible before 1933 have now become strongly centralized.

Again, recognition must be given to vestiges of dual federalism, both in the law and in the dynamics of politics. Thus there is continuing rivalry among the states in the competition for industrial development; there is regional division on some major issues; and the Supreme Court has made some cracks even in the monolithic powers derived from the Commerce Clause (National League of Cities v. Usery, 426 U.S. 833, 1976). As Lowi has written, however, the system is now a "modern, positive national state," if also "the youngest consolidated national government" among the large modern nation-states (1978: 25).

\section{Deil Wright on Phases of Modern IGR (1933-Present)}

On the basis of political and especially administrative history and practice-that is to say, without much attention to judicial doctrines of federalism-Deil Wright (1974: 7-16; 1978: 45-66) formulates several models of intergovernmental relations. They are chronologically successive but also overlapping.

First is the "cooperative" model of IGR, exemplified by New Deal innovations in grants-in-aid-a model brilliantly analyzed and denominated "the New Federalism" by Jane Perry Clark (1938)-which continues to characterize the system until the 1950s, at least in some particulars.

Second is the "concentrated model," evident from the 1940s to the $1960 \mathrm{~s}$, when the system of IGR "became increasingly specific, functional, and highly focused-in short, concentrated" (Wright, 1978: 48). Programs expanded in number and size, and an increasingly important role came to be played by professionals, whose sense of community and networks of influence tended to cross state-federal-local as well as regional lines. "Potent political alliances" emerged, connected to specific grant programs (Ibid.: 51). The specialized committee 
organization developed in Congress and suburban, middle-class special interests benefited greatly from the grants-in-aid.

The third model is "creative" IGR (1950s-1960s), in which the Johnson administration experimented with (1) program planning, (2) project grants and demonstration grants, and (3) popular participation. Policy was characterized by a skewing of state and local budgets, application of cost-benefit analysis (generally with a conservative bias), and a shift in grants emphasis toward core cities and the poor. ${ }^{13}$ The great proliferation and diffusion of this period is seen by Wright as "a flowering federalism" (Ibid.: 58).

Finally, the "competitive" model (1960s-70s) describes the Nixon-Ford-Carter period in terms of several salient characteristics, principally competition in the form of both programmatic and administrative tensions. There has been programmatic conflict between core city and suburban interests (the poor and the white middle class); over the Nixon impoundment and cutback efforts, especially the attenuation of the War on Poverty; and among cities, regions, and states for grants-in-aid. On the administrative side, Wright cites the "vertical functional autocracies" in welfare, education, etc. (which others generally have termed the bureaucratic and professional communities) and their tensions with area-based officials as well as with newly strengthened public-interest organizations such as the National League of Cities or the Council of State Governments. Wright's emphasis on the qualitative change in IGR is reflected in his statement that most officials throughout the federal system presently "appear reasonably realistic about the interdependencies within the system and about the inability to turn the clock back in IGR" (1978: 61).

In none of these three historical constructs is there even a trace of the skepticism Riker expresses (see p. 664, supra) in condemning federal structure as a mere legal fiction. Changes in the structure of government, in constitutional doctrine, in styles of administration, and in the political realities of both federalism and IGR are all regarded as having had important effects on governance and policy outcomes.

Our next main task is to look more closely at these variables in their historical dimensions. But first an additional complexity must be acknowledged and explored: the

\footnotetext{
13 Wright indicates that his characterization of this period is close to my own (1978: $55 \mathrm{n} .22$ ); hence the two interpretations converge, at least with respect to IGR as an element of working federalism.
} 
persistence of significant decentralization and diffusion of power in the American system.

\section{RESIDUAL ELEMENTS OF DUAL FEDERALISM}

Some students of the federal system take the position that centralization since the New Deal has deprived the states of any meaningful autonomy. Thus A.S. Miller has argued that the states have been "bypassed by the movement of history"; although they "still exercise a great deal of control over individuals. . . that control tends to be in matters of relatively minor or purely local importance," or else merely in programs financed and initiated in Washington (1976b: 201-02).

This version of modern federalism, which accords with the "federalism-is-dead" arguments of Kurland and others (supra, pp. 665ff.), differs from that suggested by the three historical models summarized above. Those historical arguments contend only that the present system is centralized relative to earlier periods in the history of American federalism, not that it is the equivalent of a unitary system. A brief summation of some of the evidence on this issue will illustrate the problems in distinguishing matters "of relatively minor or purely local importance" (Miller, 1976b: 201-02) from those in which state action indicates meaningful autonomy.

First, there is the continuing concern with principles of federalism in formal jurisprudence. In National League of Cities v. Usery (426 U.S. 833, 842-43, 1976), the Supreme Court signalled its determination to give renewed importance to what has been termed "formal federalism," 14 declaring that functions vital to the integrity of the states "or [to] their ability to function effectively in a federal system" were constitutionally protected from regulation by the national government. The issue in National League was the applicability of the Fair Labor Standards Act (88 Stat. 58, 1974) to wages and hours of state and municipal employees. The Court rejected the claim of Congressional authority under the Commerce Clause and

14 See Baker (1977: 172, 178). The National League decision has inspired a great many commentaries, at least two of which (Tribe, 1977; Michelman, 1977) suggest that the Court's reference to "integral" and "indispensable" functions of the states could (or ought to) increase the states' obligations to provide certain minimum services. While this may be an outcome devoutly to be wished, it does not seem likely to be pursued by the Court's National League majority.

There is, of course, a line of recent decisions in which federal courts have attempted to enlarge the affirmative obligations of the states. They have done this despite the warnings of conservative commentators (e.g., Friendly, 1977: 1028), and the Burger Court has not always validated such judicial initiatives (Mishkin, 1978; cf. Rizzo v. Goode, 423 U.S. 362, 1976). 
declared that control over the terms of employment of state and municipal workers was one of those powers "essential to [the] separate and independent existence" of the states (426 U.S. 833, 845). Distinguishing Congressional legislation regulating business, or even the less "essential" functions of the states (not clearly defined), from regulation impinging on the authority of "the States as States" (426 U.S. 833, 835), the Burger Court clearly sought to revitalize legalistic forms of sovereignty. The rhetoric of the decision-even if one agrees with Tribe's criticism of "talismanic invocations of federalism" (1977: 1104) - suggests a potentially broad reach: the Court curtails Congressional power in areas that are variously referred to as "integral parts of their [the states'] governmental activities," "traditional," or "essential" (426 U.S. 833, 851, 854, 845-47; see Michelman, 1977: 1172).

One is left wondering how the National League formula may affect reappraisal of the apportionment question, surely more central to the power of "the States as States" than policies regarding municipal workers' wages; indeed, the Court's reasoning comes remarkably close to reviving longdiscarded doctrine that extended tax immunity to the incomes of state and local officials (Collector v. Day, 11 Wall. 113, 1871; see Graves, 1964: 446). Lest such an extension seem farfetched, it is well to recall that National League not only reversed law reaffirmed as late as 1968 (Maryland v. Wirtz, 392 U.S. 183, 1968) but was the first decision in forty years (see Carter v. Carter Coal Co., 298 U.S. 238, 1936) to find Congressional power inadequate under the Commerce Clause by reason of state sovereignty and federalism. One year after National League, the Court reiterated its respect for "formal federalism" when it ruled that the states had the power to act on matters affecting riverbed lands (Oregon v. Corvallis Sand \& Gravel Co., 429 U.S. 363, 1977), again overturning a recent decision reaffirming centralizing doctrine (Bonnelli Cattle Co. v. Arizona, 414 U.S. 313, 1973).

National League must be understood, moreover, in the context of earlier Supreme Court decisions indicating that the obituary notices for dual federalism may be highly premature. Most noteworthy of these was the Younger decision, in which Justice Black spoke for the Court in declaring that "our federalism [demands] a proper respect for state functions . . . and a continuance of the belief that the National Government will fare best if the States and their institutions are left free to perform their separate function in their separate ways" 
(Younger v. Harris, 401 U.S. 37, 44, 1971). Since that time the Court, usually over strong dissents, has invoked federalism in a series of rulings that severely reduce federal court oversight of state court procedure, reduce or eliminate federal constitutional barriers to state actions affecting civil rights and civil liberties, and stay the hand of lower federal courts mandating institutional reform or structural change in cases in which equal protection rights have been at issue. ${ }^{15}$ In addition, the Court has deferred to state autonomy in the areas of zoning (Village of Belle Terre v. Boraas, 416 U.S. 1, 1974) and school financing (San Antonio School District v. Rodriguez, 411 U.S. 1, 1973). More recently, in the New Melones Dam decision (California v. U.S., 438 U.S. 645, 1978), the Court reversed its previous interpretation of Section 8 of the 1902 Reclamation Act (32 Stat. 388, 1902; 43 U.S.C. $\S 391,1976$ ) to rule that the states have authority to allocate water from reclamation projects. The majority opinion requires the national government to conform to procedural requirements imposed by the states and to state law governing distribution and private use of water in these projects. To be sure, the Court reaffirms the primacy of congressional "directives" in the definition and pursuit of national objectives. Yet, as one commentator has written, the decision has "abruptly changed the course of western water law" and "by acommodating federal and state interests rather than perpetuating a pervasive federal supremacy, the Court gave rebirth to the tradition of federalism in the field of reclamation" (Walston, 1979: 1646). Although the Burger Court has certainly not issued a wholesale renunciation of earlier doctrine, it has dramatically demonstrated that doctrines of formal federalism significantly limit the reach of congressional power and the scope of federal judicial remedies.

Meanwhile, the Burger Court has left state courts free to interpret their own constitutions independently as long as they hold their officials to a higher standard than that mandated by the federal Constitution, even when the relevant language of the two is similar or identical (Brennan, 1977; Howard, 1976). The California high court has made the greatest use of this autonomy, frequently basing its criminal-process and freespeech decisions on "independent state grounds." 16 Thus it

15 Among the leading cases are: Younger v. Harris (401 U.S. 37, 1971); Samuels v. Mackell (401 U.S. 66, 1971); Paul v. Davis (424 U.S. 693, 1976). See Friendly (1977: 1030); Fiss (1977: 1103ff.).

16 In 1974, California voters adopted an amendment declaring that "[r]ights guaranteed by this Constitution are not dependent on those guaranteed by the United States Constitution" (CAL. CONST., art. I, sec. 24). 
found capital punishment unconstitutional under the state's own basic law (People v. Anderson, 6 Cal. 3d 628, 1972), established a double-jeopardy standard higher than the federal one (Curry v. Superior Court, 2 Cal. 3d 707, 1970; People v. Hood, 1 Cal. 3d 444, 1969), and required equality in school financing by local districts, directly contrary to the federal interpretation of equal protection in the Rodriguez decision two years later (Serrano v. Priest, 5 Cal. 3d. 584, 1971).

Echoes of dual federalism are again heard in judicial halls. Justice Mosk of the California Supreme Court, a leading champion of independent state grounds, denounced the notion that state interpretation ought to conform to the federal rulings on individual rights as potentially "a serious blow to state sovereignty. . . ." (Diamond v. Bland, 11 Cal. 3d, 331, 340, 1974, dissenting). Justice Brennan has welcomed state court application of the independent-grounds doctrine.

Every believer in our concept of federalism ... must salute this development in our state courts. Federalism must necessarily be furthered significantly when state courts thrust themselves into a position of prominence in the struggle to protect the people of our nation from governmental intrusions on their freedoms. [1977: 994]

Legal scholars have responded to these developments with varying degrees of enthusiasm. One commentator points out that when state judges base their decisions on the state constitution, they avoid review by the federal courts and simultaneously foreclose any response by the state legislature (American Criminal Law Review, 1976: 778). Others (e.g., Arons and Katsh, 1975; Howard, 1976) are substantially in agreement with Judge Mosk's version of the classical view of federalism as an instrument of freedom:

Encouraging the fifty states to experiment, to retain their historic individuality, to seek innovative responses to problems of protecting individual liberty, may ultimately produce more of the answers [than will reliance on the national government] in the century ahead. . . . Using the state constitution in this way is no mere scheme to thwart federal review by the current Court, though that may be a salutary byproduct. And though some fragmentation may occur ... the expanded liberty of individual citizens that this approach makes possible fully justifies any absence of seamless uniformity. [1978: 5]

The net impact of the Burger Court's new solicitude for traditional state sovereignty, however, has been erosion of the protections for civil liberties established by the Warren Court: California is the exception, not the rule (Harvard Civil RightsCivil Liberties Law Review, 1973; Alarcon, 1979). One may gain some useful insight into the motivation of Chief Justice Burger,

In People v. Norman (14 Cal. 3d 929, 939 n.10, 1975) the recently adopted provision was termed a "declaration of constitutional independence." Cf. Alarcon (1979); Newman (1979). 
at least, from his public statement a few days after National League of Cities was decided: "We took steps to arrest the denigration of states to a role comparable to the departments of France, governed entirely out of the national capital" (quoted in A.S. Miller, 1976a: 26). But although the surrender of federal power signifies attenuation of the protection of individual rights by the U.S. Supreme Court, increasing diversity in state constitutional law, it also provides vivid evidence of residual dual federalism in the contemporary legal system.

A second major element of residual dual federalism appears in the dynamics of state policy. There is continuing interstate rivalry, especially in the manipulation of business and corporation law, including taxation, to make states attractive to potential investors. This is attacked in a recent report by Nader's Public Interest Research Group (1979), which estimates that corporations currently receive over $\$ 700$ million in subsidies from competitive tax policies and bond support. State and local economic development programs are condemned as "chaotic and work[ing] at cross purposes with one another" (Ibid.: ii). Evidence of the political seductiveness of such policies is the record of California Governor Jerry Brown. After two years of stressing "less is better," environmental control, and the like, the governor shifted gears to feature buttons on staff members' lapels reading "California Means Business." The state economic-development director complained: "We can't rely on our good luck any more: We have to get out and hustle." Yet he admitted with embarrassment that his budget was too small to permit him "to track 'raiding parties' from other states attempting to lure industry away" (quoted in Broder, 1978: 37; Business Week, Feb. 7, 1977: 38).

According to state officialdom, the need to "hustle" stemmed from the fact that California offered corporations a mix of environmental laws, bonded aid to corporations, tax exemption, labor legislation, and the like less attractive than that found in other states. Moreover, the reference to "raiding parties" is a reminder that state and local governments are resourceful in locating the canyons and ravines where they can breach the modern federal system to their particularistic advantage. Indeed, the corporate raiders often operate in broad daylight during the most serious crises-witness the vigor with which New Jersey recruited New York business firms in 197677 , stressing the desirability of flight from the city's fiscal crisis and its probable costs to taxpayers. 
For analytic purposes-including comparison with past eras of American federalism-it is important to recognize that state differences in the legal climate of business and investment do indicate a meaningful diffusion of power. Such rivalries generate pressure to reduce social and economic legislation to the lowest common denominator (Macmahon, 1972: 59-61). This is what Justice Brandeis once termed "competition in laxity," by which all states, selling their products in a single market, are compelled to reckon the costs carefully when they undertake to regulate business interests. The most lax (or beneficent) regulatory policy places serious pressure on all the rest of the states (Cary, 1974: 663; Friedman, 1973: 375-78).

A third element of contemporary dual federalism is found in the dynamics of regional coalitions. The extended series of policy debates inspired by sectional jealousies and animosities, the controversy between Sunbelt and Snowbelt (see National Journal, June 26, 1976: 878; Phillips, 1978), was termed by New York's governor "the final step in a trilogy of wars of separation," the first two being the Revolution and the Civil War! The coalition of northeastern and midwestern states, he said, was "not an effort in separatism, but in regionalism" (Carey, 1977: 27). Other governors spoke in terms of a new War between the States or a New Balkanization. In 1978, the arena of controversy shifted somewhat: the "Sagebrush Rebellion" involved formal votes in many western legislatures (and Alaska), either demanding federal surrender of public lands or else threatening outright to challenge federal authority over such property (see Jean, 1978: 6-7). Nevada enacted a bill asserting state sovereignty over federal land, and as the movement gained adherents in the public-lands region, Alaska's lieutenant governor proclaimed that "the MasonDixon line ha[d] shifted" so that now it separated East from West. Governor Lamm of Colorado, an articulate spokesman for regional interests, was sufficiently embarrassed by parallels with southern claims in defense of segregation that he explicitly promised that despite his assertions of state sovereignty, he was "not going to stand in the schoolhouse door" (quoted in Broder, 1974: 5; Lamm, 1979). Such regionalism is also pursued through compacts and other formal structures (Wilson, 1977).

The primary informal instruments used in creating regional coalitions-bloc organization in Congress and regional collaboration by governors-are reminders of the importance of 
formal constitutional structures. For as Wechsler argued, "the continuous existence of the states as governmental entities and their strategic role in the selection of the Congress and the President" ensure attentiveness and loyalty to local interests (1955: 98). ${ }^{17}$.

Finally, there is a fourth element, less tangible but nonetheless influential-considerations of federalism" in the nation's political dialogue. By this I mean sensitivity to the classic concerns of federalism: the positive value of government close to the people, awareness of the need for a "proper" balance of state and national power, and the like. It is, of course, difficult to judge whether such concerns are merely a smokescreen behind which special interests are pursuing blatantly self-serving goals. Still, the very fact that business and other special-interest spokesmen as well as politicians believe that such values sway the public is an indication of either genuine belief in federalism or cynical manipulation of its symbolism (or both). The American political consciousness has not been purged of its inherited notion that certain enduring values are served by federalism and decentralization.

The content of these values needs to be examined next since they provide some important criteria for judging the system's past performance.

\section{THE TRADITIONAL VALUES}

Historical investigations of federalism can usefully focus not only upon institutional and doctrinal change but also on the traditional normative issues. Central to any such inquiry is the question: How much power ought to be permitted at the center (the national government), and how much should be retained by the constituent governments (the states)?

Even the most cursory recapitulation of the values of federalism must begin with the merits of government that is "close to the people." Formal theories of federalism and the

17 Baker (1977: 183-84) offers an extended critique of the logic of Wechsler's argument, also contending that political and constitutional changes since 1954 have undermined what elements of Wechsler's view were valid when he wrote. Mathews (1970) examines a fascinating example of how Congress can react to special-interest pressures that seek to curb state powers and impose more rigid limitations on the states than those imposed by the Supreme Court. See his discussion of Northwestern States Portland Cement Co. v. Minnesota (358 U.S. 450,1959$)$, in which the Court permitted states to tax the net income foreign corporations derived from interstate operations and the legislative aftermath, as Congress moved quickly to curb the effect of that ruling. 
core content of American political rhetoric and ideology have both addressed this problem; in each case, there is a conviction that strong government at the state and local levels will serve to guard against the sort of "plenary \& consolidated Government" that the Founders attempted to prevent with the compromises of 1787 (James Madison, in Farrand, 1937: 517). Diffused governmental power and state control over important functions work against alienation; they involve the voters in governmental affairs, encourage participation, and maintain the vitality of "grass-roots democracy." State and local government will be more responsive to the needs of their constituencies and more responsible since the citizenry will be better informed about local officials and policies. Where cultural or ethnic divisions are territorially based (not the case in the United States now, or even in 1787, unless Southern black slavery be considered such a distinguishing cultural feature), federalism permits the central government to relegate to the states various issues that would be highly divisive if settled at the national level; in such situations, a federal structure affords room for cultural diversity of expression and growth. Diffusing power by allocating separate functions to the national and constituent states is a bulwark of individual liberties (see Gilbert and Smith, 1968: 1244ff.; Strong, 1976: 127; Grodzins, 1963). Moreover, as Beer has shown, the problem of effective representation was at the heart of the original understanding of 1787 , so that "the social pluralism of the nation as a whole would be represented in the general government," while diversity was given wide play in the states (1978: 13-14; see also Scheiber, 1978a).

A second cluster of values concerns the effectiveness of governmental performance rather than the imperatives of liberty and representation. Few political ideas have found so warm a reception throughout American history as Madison's assertion that if the states were abolished "the general government would be compelled by the principle of selfpreservation, to reinstate them in their proper jurisdiction" (The Federalist, No. 14, 1961: 86). In this vein, Adlai Stevenson wrote that the power of the states

to pass upon and decide local affairs is one of the very great assets of our free society, making possible democratic participation at the grass roots of our human relations. If our $\mathbf{1 5 0}$ million people did not have the states they would create them, rather than centralize all power at one point where congestion of authority would soon defeat the purposes and possibilities of democratic development and progress. [1950: 5]

Consistent with this style of thought is contemporary concern, stimulated especially by administrative confusion and turmoil 
of the mid-1960s, to distribute functions more efficiently between the states and the national government so as to solve the problems of fragmentation, administrative overload, and complexity (Walker, 1974: 20-22). There is also a rapidly growing literature on the application of efficiency models to the problems of federal division of powers; beneath all the algebra and the invocation of economic terminology lies the conviction that efficiency can usefully be extracted from the larger complex of values that secure our attachment to federal government (see, e.g., Breton and Scott, 1978).

But there are some who view the federal structure as an impediment to effective government in the modern world. Thus Harold Laski announced an end to "the epoch of federalism" forty years ago because he found federalism "insufficiently positive in character; it does not provide for sufficient rapidity of action; it inhibits the emergence of necessary standards of uniformity" (1939: 368). Many observers of their performance have concluded that state and local governments are incapable of delivering the requisite services by reason of their very multiplicity; susceptibility to special-interest pressures; and failure to mobilize funds, expertise, and efficient bureaucratic organization. Indeed, in the 1950 s and 1960 s it was common to regard the states as hopelessly inefficient, "sick" and corrupt. Today, after Watergate and a period of reform in state and local governments, there is generally more faith in the constituent units (compare Adrian, 1964 and Wright, 1978).

Another potentially fruitful area of historical analysis is suggested by the claim of Mr. Justice Brandeis: "It is one of the happy incidents of the federal system that a single courageous state may, if its citizens choose, serve as a laboratory, and try novel social and economic experiments without risk to the rest of the country" (New State Ice Co. v. Liebermann, 285 U.S. 262, 311, 1932, dissenting). The states, as Holmes declared, afford "insulated chambers" in which community desires for such experiment can find room for expression (Truax v. Corrigan, 257 U.S. 312, 344, 1921, dissenting opinion). To be sure, positive guarantees of individual freedom or minimum national standards may demand uniformity. Appraisal of the role of the states as experimental laboratories requires a thorough historical understanding.

The need for historical inquiry relating the claims of federalism to its values was suggested by the late Robert McCloskey. 
Do we want a federalism in which the national government's powers are almost unrestricted, its purposes unconfined, its ascendancy over the states indubitable, and its relation to the states one of paternal collaboration?...

The idea that governmental purposes and societal needs are something less than coterminous may still have some merit in America. And there may remain something to be said for local vitality as a protection against tyranny and as an alternative to static national uniformity.

But whatever the conclusion that may be arrived at, one point seems clear-that there is nothing at all to be said for letting the question be answered by default. . . It is still important that we realize what has happened ... and that we take careful stock of the constitutional values that have been vitiated as well as those which have been elevated to a new place. [1957: 184]

\section{MEASUREMENT OF CENTRALIZATION AND DIFFUSION}

We need some measure, however rough, of the centralization and diffusion of power, ${ }^{18}$ although it need not, and probably cannot, be purely quantitative. The following theoretical considerations regarding power and diversity in federal systems bear on this problem.

Not all governmental powers are equally important. The analysis of centralization or diffusion must distinguish between powers that can transform the lives of citizens and powers that can have only a trivial impact even when exercised to their fullest extent. Some historical studies of American federalism fail to make such a distinction. Admittedly, the task is difficult and in some ways profoundly subjective (see Scheiber, 1966: 24).

A vital distinction must be made between formal authority and real power. Some analysts have gone so far as to contend that societies are "federal" or "nonfederal" depending on the extent to which their constituent jurisdictions resemble one another in social profile, political ideology, and the like; such analysts view discussion of formal constitutional doctrines and the like as far less illuminating than issues such as symmetry"the level of conformity and commonality in the relations of each separate political unit of the system to both the system as a whole and to the other component units" (Tarlton, 1965: 867). Although this approach may yield information concerning what Tarlton terms "secession-potential" (Ibid.: 870), I am suggesting something rather different here. In the distinction between formal authority and real power, the focus of analysis is on decision-making powers and the implementation of those

18 The content of the next few paragraphs follows a discussion of theoretical considerations in a paper for the 15th International Congress of Historical Sciences, Bucharest, a version of which will be published in Poland (Scheiber, 1980). 
decisions, rather than on the macro-societal dimensions that concern Tarlton.

Formal authority, in the American system, is the body of doctrine ("constitutional law") found in the original Constitution and in the interpretations of the Supreme Court. At a given moment in time, one can "map" the formal powers of state and national governments by reference to the Court's decisions, which provide the substance and boundaries of the inquiry.

But formal authority is only one component of real power-the actual exercise of coercive authority by the governmental units in the federal system. If the exercise of real power conforms to prescribed formal authority, then it is legitimate (in the legalistic, not the moral sense). A concern with real power brings us to the behavior of government, as opposed to the formal judicial prescriptions of how government ought to behave (see Scheiber, 1975a; cf. Jaskiernia, 1979).

Other components of real power include: (a) the degree of congruence between geographic jurisdiction and the governmental function to be performed; (b) the competence of the governmental unit, measured by its command of fiscal resources, recruitment of expert personnel, sufficiency of administrative structure, and, more generally, possession of resources adequate to implement policy; ${ }^{19}$ and (c) the existence of a political situation that permits effective action. On the last point, it should be clear that well-organized special interest groups can galvanize government into action or focus attention on a single issue (tax policy, corporations, regulation of business, abortion or family law); "majority rule" is not equivalent to effective will. Indeed, Madison argued for extending the size of the republic precisely in order to offset the tendency of local or transient majorities to tyrannize (The Federalist, 1961: especially no. 10).

A genuinely decentralized federal system, therefore, is one in which the constituent state governments have not only formal authority but also real power to act in matters of substantial importance (see Livingston, 1952). Analysis must consider the range, content, intensity, and impact of governmental policies at both the national and state levels.

19 In the writings of Willard Hurst, these dimensions of "competence" are subsumed in the concept of autonomy. Hurst has written extensively (e.g., 1960) on the relatively weak autonomy of nineteenth-century state government, by which he means that the states lacked the expertise, administrative structure, and political support to define and pursue the "public interest" in opposition to special-interest pressures. See text below at note 22 . 
The student of the federal system, having attended to all the foregoing concerns that bear on legitimacy and decision making, must acknowledge Tarlton's concerns and also deal with the degree of centralization in the private sector of the economy and the organization of power in society (see, e.g., Miliband, 1969: 52-54). Thus A.S. Miller claims that the "supercorporations" in the contemporary American economic order actually organize and mobilize people (and also make essentially political decisions) in ways that rival the states:

Each of those enterprises, although a "person" in law, is in fact a collectivity, a federation of interests, a sociological community, a private government, a political order. Taken together, they make up the "corporate states of America"-a type of federalism that is of fundamentally more importance than is the system of federalism . . . established by the Constitution. [1976b: 126-27]

Analysis of the federal system must be concerned with diversity among the states in the exercise of political power. Does the "mix" of laws, administrative policies, and constitutional structure differ significantly from state to state?

To be sure, a unitary nation can promote diversity of state policy by devolving a wide range of significant decision-making or administrative powers touching vital local or provincial interests or expressing territorially based cultural groups. As Young notes, moreover, simply by "multiplying the arenas of negotiation and brokerage of competing claims," even a modestly decentralized federal structure can defuse potentially dangerous pluralist rivalries and jealousies (1976: 526). ${ }^{20}$

In the case of the United States, however, the constituent states are likely to press their claims to control matters of vital interest as an issue of constitutional right, and not merely of policy. The more essential the interest, the more likely that this escalation will occur, as happened with slavery and is now happening with the formulation of natural-resource policy, though on a lesser scale. The national government can, indeed must, respond to such pressures as it did in the great nullification crisis or the Civil War, but it does so at the risk of provoking secessionist responses. The very potency of constitutional arguments can encourage efforts by the states to enlarge their claims to formal authority, defend established

20 Young's work treats numerous cultures and polities of the contemporary Third World, exploring in depth many theoretical themes introduced in Wildavsky (1964). The recent work of Dikshit (1975), which is mainly concerned with how geographers ought to treat federalism, covers some of the same ground but far more superficially. His treatment of U.S. federalism relies mainly on survey textbook accounts. A recent set of essays on federalism and ethnicity probes the problems of pluralism and political structure (Publius, 1977; see especially Ducacheck, 1977). 
areas of autonomy, and guard jealously against erosion of their formal powers, even at the cost of temporary sacrifices. When Massachusetts and other states challenged the power of the national government to attach conditions to grants-in-aid, for example, they had to contemplate the possible loss of such aid (Massachusetts v. Mellon, 262 U.S. 447, 1923).

Livingston has shrewdly observed that as new states came into the Union both in the older regions and the newly won West, they "rapidly acquired such consciousness of individuality" that they quickly learned to use the instruments of constitutional politics to make formal claims of authority: "The Constitution, which endows the states with the characteristics of diversity, treats them indiscriminately and thus tends to create diversity where none previously existed" (1952: 92).

If we discover that the constituent states in a federal system are engaging in policies that are diverse in content, impact, and motivation, then we have evidence of decentralized real power. If such diversity should diminish over time-which I contend has occurred in the United States-then the system is becoming more centralized. The national government comes to lend more direction to policy, and it imposes uniform national standards and central administration.

Even under centralization, there may still be considerable diversity among states on lesser matters (see A.S. Miller: 1976b: 202). Furthermore, it is possible to retain some elements-indeed very prominent elements-of the formal administrative structure of a decentralized system while centralizing real power. This, of course, is the fascinating core of contemporary studies of intergovernmental relations by Deil Wright (1978) and others: state and local bureaucracies are given a role in the administration of many programs for which most or all of the funding, policy content, conditions, auditing, and final supervision is in the hands of the central government or its creatures, such as regional councils of administration. This use of the state and local apparatus-the essence of the "Cooperative Federalism" prevailing since 1933-is termed "sharing." How to assess its effects on power distribution is a matter of great controversy among scholars, as has been shown (supra, 670-78). So too is the history of such sharing, which a few view as continuous in American history but which others (including myself) feel is qualitatively different in the modern period. 


\section{SURVEY OF HISTORICAL INQUIRIES}

In recent years, both historians and political scientists have expressed optimistic hopes that we can achieve a better understanding of how socioeconomic development relates to legal process and to policy outcomes in the federal system. Samuel Beer's historical model for example, is based on a moving counterpoint between the themes of "modernization" and "governmental change" (see p. 679, supra); unfortunately, the historian finds Beer's construct extremely abstract and wanting in systematic evaluation of empirical evidence for the long period prior to 1933. In other writings, one finds an emphasis upon the parallel development and functional interplay of "urbanization" and changes in federalism (e.g., Elazar, 1975); the evolving interrelationships between dominant types of policy decisions and party development (Beer, 1973; Lowi, 1967); and stages of economic development as determinants of each state's decision, at varying points in time, to adopt or abandon an interventionist strategy for either promotional or regulatory purposes (Goodrich, 1968). My own efforts have been devoted to assessing the relationship between federal constraints and opportunities on the one hand and the policy objectives and styles of individual states on the other (e.g., Scheiber, 1975a).

As all these lines of study indicate, the historical analysis of public policy can be usefully linked to contemporary scholarly concerns. To date, the linkage has been tentative, often abstract, and characterized by the all-too-familiar difficulties that stem from cross-disciplinary window-shopping as a substitute for real mastery of the techniques and research findings that historians borrow. Mindful of these pitfalls, I would still like to attempt a rough classification of the studies that are relevant to an analysis of federalism and legal process in American history. Throughout the discussion, I will seek to relate these studies to the dimensions of centralization identified in the previous section.

First there is the problem of empirical data. For the entire period prior to 1902, when the U.S. Census Bureau's Historical Statistics began to employ special governmental surveys as well as the decennial Census, only highly aggregated statistics are readily available on such vital matters as state and local expenditures and revenues, debt, public employment, and bureaucratic structure and distribution of personnel by function. Fortunately, we now have a systematic analysis of nineteenth-century revenues and expenditures (Davis and 
Legler, 1966: 514-52) together with useful statistical studies of intergovernmental transfers (Trescott, 1955; 1966). Historians therefore face the difficult task of generating estimates that will be continuous with the standard modern governmental statistical series. ${ }^{21}$ As far as the federal government itself is concerned, Van Riper was forced to work from primary sources when he sought to reconstruct the numbers and functions of United States and Confederate States workers in the Civil War period $(1958,1959,1965)$. In his important studies of the national bureaucracy from 1790 to the end of the Republican postbellum era, Leonard $\mathrm{D}$. White has provided a model of administrative history (e.g., 1948), but as yet we have nothing comparable for any state. Thus, "mapping" the functions and resource allocation of the various state agencies remains a burdensome undertaking. Only G.D. Nash (1964) has attempted to do it for California from 1850 to 1933 , and he is concerned almost exclusively with government and the economy, not with intergovernmental relations. For the period since the 1870s, Sidney Fine's classic study of the origins of the modern welfare state (1955) pointed the way, while the very ambitious'new work by Morton Keller, Affairs of State (1977), treats structure, policy, and social change on a large canvas-a portrait of the "legal culture" of the Gilded Age. A few specialized analyses of nineteenth-century governmental institutions and agencies also contribute to our understanding of the day-to-day operations and impact of early bureaucracies (cf. Crenson, 1975; Scheiber, 1969, 1975: 60 n.6; Nelson, 1976).

For the modern period, of course, statistics on governmental employment and finance are much more satisfactory. They provide the data base for such standard works as Maxwell and Aronson on state and local finance (1977), Reading on state and regional expenditures under New Deal programs (1973), and a variety of recent attempts to relate quantifiable governmental activity to public policy and political behavior (cf. Jacob and Lipsky, 1968). The standard treatise on IGR (Graves, 1964) contains a wealth of historical material. Elazar (1962) attempts to isolate patterns of IGR in a major study that is unfortunately flawed by his failure to consider

21 The U.S. Census data, including the special collections of statistics on government employment and finances, provide fairly full series from 1902. The Council of State Governments and other sources offer disaggregated data on expenditures by function, etc., for the very recent period (especially since 1950), and the annual federal budget contains a detailed breakdown of intergovernmental transfers by function, region, and the like. 
important historical writings and to distinguish more and less significant intergovernmental contacts and programs. Still, the book seeks to use case studies in an imaginative way to illustrate the range of relationships. No less important is the glimpse it affords of differences among states that are geographically distant and developmentally divergent: New Hampshire, Minnesota, and Colorado.

Beyond the rudimentary empirical reconstruction of how government was organized and financed, we find a second major concern in the literature: the range of differences in state policy. Virtually every piece of evidence uncovered and every new analysis of a previously neglected governmental function or jurisdiction reinforces the picture of great diversity in the nineteenth century. A few examples will suffice. Freyer has shown that it was precisely the persistence of state-bystate differences in rules of commercial law in the antebellum period and in later years that made the movement for a federal common law and the doctrines of diversity jurisdiction such vital issues in their day $(1976,1979)$. Horwitz's study of property law in the northeastern states before 1860 (1977), Lauer's research on water law $(1963,1970)$, and my own writings on nineteenth-century eminent domain $(1972,1975 b)$ indicate that there were thoroughgoing differences in the judgemade rules of the various states on matters of central importance to localized patterns of economic development. Even in the laws governing slavery, scholars have found major doctrinal differences in the courts of the individual southern states (A.E.K. Nash, 1970; cf. Tushnet, 1975). Leading studies of transport policy and its effects on the economy reinforce the impression of diversity and decentralized real power (cf. Goodrich, 1968, 1970). So also do excellent new studies of judge-made state law on the subject of nuisance-a key factor affecting entrepreneurial costs (Kurtz, 1976)-and of the doctrinal development of the police power (Reznick, 1978).

Hurst's magisterial work (1964) on the Wisconsin lumber industry offers a uniquely comprehensive view of how the whole range of state law shaped and constrained a single industry; he stresses not only the importance of state law in franchising, allocating, and regulating but also the "federal effects" on the industry's development. In the latter category he includes the pressure on Wisconsin to avoid effective regulation because the common national market would have given lumbermen a strong incentive to invest and cut timber elsewhere. James Wright (1974) has brilliantly delineated the 
impact of differing state laws on social and political conflict during the Populist period in his study of the "three-party system" in Colorado. His findings are reinforced by examination of the bloody labor conflicts that erupted in the mines of the same region (V. Jensen, 1950). The forthcoming work by Friedman and Percival (1980) on criminal justice in Alameda County, California, will offer a data base from which to proceed with systematic comparative study of substantive law and legal process in this area, just as Kagan and others (1977) have recently established a basic framework for the comparative quantitative analysis of the work of state supreme courts.

New research is most likely to uncover evidence of diversity in the uses of real power to regulate family relations, morals, and social behavior generally. Friedman's pathbreaking general history (1973) undoubtedly gave legal history new impetus, especially since it converged with the appearance of new work by Hurst $(1964,1970)$ and the publication of two major collections of essays, one reprinting classics on colonial legal history (Flaherty, 1969) and another presenting original essays (Fleming and Bailyn, 1972) that immediately generated extensive comment (e.g., Holt, 1974). The most provocative part of Friedman's comprehensive framework for legal history is in the field of social policy. Lately Gerald Grob (1976, 1979), a leading student of social policy, has added to the impression that significant diversity characterized important areas of the law in the working federal system of the nineteenth century (see also Zainaldin, 1979; Zainaldin and Tyor, 1979). The most dramatic evidence of all, perhaps, is in Coleman's study of debtor law (1974).

As the foregoing discussion suggests, a major contribution of the recent literature has been to extend our knowledge of the scope and actual content of policy, which was long limited to a reading of state statute and constitutional law. Now however, it includes a fuller appreciation of judge-made law. Here, again, Hurst blazed the path (cf. Gordon, 1975; E. Murphy, 1964; Scheiber, 1970), presenting case law in his exposition of themes such as "drift and default" in policy, "release of energy" through reliance on contract and market relationships, and what Hurst variously called "instrumental" or "pragmatic" attitudes toward the encouragement of material growth.

As this line of scholarship has been further advanced by intellectual historians who have developed major hypotheses 
about "judicial style," it has generated considerable academic controversy. In a widely noticed book of essays, Horwitz (1977) relies upon the scant evidentiary base of judicial decisions from a few northeastern states to support conclusions about "the transformation of [all of] American law." As I have contended elsewhere (1977), it is impossible to credit Horwitz's claims about the exploitative effects of instrumentalism in the decisions of American courts because he entirely ignores the regulatory side, despite the existence of studies on police power by Hurst (1964) and Levy (1954). Still, the raw evidence unearthed by Horwitz from a variety of sources clearly demonstrates that judicial attitudes were a major element in the differentiation of state laws. Beyond the eastern region from which Horwitz draws his evidence, one finds a mixture of judicial innovation, borrowing, and adaptation to meet the needs of advancing technology in new places (Hurst, 1964; Scheiber and McCurdy, 1975; McCurdy, 1975). William Nelson's provocative claim (1974) that "formalism" supplanted "instrumentalism" as the result of antislavery jurisprudence is an ambitious effort to impose a framework covering legal process in all the states, subsuming the differences $I$ have stressed here. But Nelson has created conceptual categories that appear too rigid and exclusive, has missed the significance of evidence for the vast region west of the Monongahela that so consistently manages to escape the attention of some legal historians, and may have based his argument on shaky philosophical premises as well (cf. Paine, 1978; Scheiber, 1975b).

As we are reminded by such studies, the traditional examination of discrete cases offers a useful lens through which to scrutinize what was happening in the constituent states. There is a "hidden side" to every Great Case in constitutional law. Normally we treat social context ("the facts") and previous litigation as mere background; as constitutional law, the Great Cases are of interest for their doctrines, building blocks in the architecture of the basic law. Some of the newer constitutional literature, however, by concentrating on social context and litigational history, further illuminates the present themes-the decentralization, if not the Balkanization, of real power in many vital areas of nineteenthcentury law, together with striking diversity among the states. A leading example of such scholarship is the succession of brilliant articles by McCurdy $(1976,1978,1979)$, which challenge head-on the conventional understanding of laissez-faire as the 
guiding light of Gilded Age jurisprudence. McCurdy makes important substantive distinctions in constitutional law between elements the Supreme Court left to the discretion of the states and elements that it (and especially Justice Field) sought to rationalize and reorder. He also allows a new appreciation of the Commerce Clause in action, illustrating how changing technology and the increasing scale of corporate operations forced reconsideration of traditional doctrine and of state corporation laws-a segment of state policy (like commercial regulation) deeply infused with protectionist and rivalistic aims.

Mann (1963) offers similar evidence on the degree of decentralized power under the Commerce Clause in his study of the long, complex litigation leading to Gibbons v. Ogden (22 U.S. 1, 1824). Notwithstanding the landmark significance of the Marshall Court's declaration of exclusive Congressional power to control interstate commerce-in the process "nationalizing" rights and liberties-it is also instructive to be reminded that more than three decades after the adoption of the Constitution no less a judge than Chancellor Kent was dedicated to the view that only "the laws and regulations of the state" should control rights in property (Ogden v. Gibbons, 4 Johns. Ch. R. 150, 157, N.Y., 1819, quoted in Mann, 1963: 181). Horwitz's studies (1977) further amplify the actual history of property rights under such premises, and my own work $(1972,1978 \mathrm{~b})$ on eminent domain and the "public" side of American law attempts to do the same, employing an evidentiary base that extends past 1860 (the terminal point of Horwitz's study) and beyond the geographic confines of the Northeast.

In the Contract Clause realm, Stanley Kutler's analysis (1971) of the Charles River Bridge Case (11 Pet. 420, 1837) has further revealed the full dimensions of decentralized, statebased power in the franchise and regulation of transport facilities. His work underlines two important points with regard to antebellum federalism: first, that the state courts operated with wide-ranging discretion in the definition of property rights; and second, that though decisions such as Charles River Bridge were explicitly concerned with states' rights (see Scheiber, 1975b: 80.81), they need not be interpreted as a derogation of national power (Kutler, 1971: 131).

Harold Hyman's study of constitutionalism in the Civil War era (1973) requires special mention because it integrates "high politics" in the most critical period of American federalism with 
the development of law and policy in the states and with rapid changes in constitutional law. It offers a valuable analysis of how "considerations of federalism"-especially residual ideological commitments from the antebellum era-attenuated efforts at nationalization of power in many policy areas. Hyman takes the position that despite the extent of constitutional change-the most important watershed in constitutional law after 1790-the failure to develop a "centralized leviathan" and the survival of "state-centered federalism" left the nation with a governmental structure little changed from that of the antebellum period (Hyman, 1973: 38182; see also Paludan, 1975; contra Scheiber, 1978a: 637). The jurisdiction of the federal courts in the context of Civil War centralization is treated fully by Wiecek (1969) and Hall (1975).

Another class of historical studies that bear on federalism attempts to construct typologies of the states. Some studies do so by reference to nineteenth-century economic policy. There is now a very considerable literature on the history of states that differed in stage and patterns of development, in policy objectives, and along other dimensions. Willard Hurst has characterized antebellum state legal process as "drift and default." Pressures in the private sector were narrowly focused; government was "underdeveloped," lacking the resources, personnel, and expertise necessary to evaluate policy issues autonomously and to assert an independent concept of the "public interest" based on a calculus of longrange costs and benefits; society pressed lawmakers for shortrun material growth and particularistic benefits, inspired by a broad consensus that gave priority to the market, private-sector values, and economic development; and the judiciary reinforced this process with pragmatic decisions that placed entrepreneurial needs above the classic "vested" rights (Hurst, 1956, 1960, 1964). Policy tended to be fragmented, incoherent, and ill-considered. ${ }^{22}$

This model accurately describes policy making, the legal process, and policy outcomes in states such as Wisconsin, but I have suggested that there was an entirely different style in the "public enterprise states" like New York, Ohio, and Pennsylvania, which adopted comprehensive plans for public construction of transport facilities, built bureaucratic

22 In a study of Congress in the Civil War era, focused on the notorious Pacific railroad land grants, Farnham (1963: 67-80) comes to similar conclusions. Government was expected to subsidize enterprise, not to govern. "The task of governing was left to private enterprise ... [creating a] basic flaw in the nation's political society" (1963: 679-80). 
structures much more elaborate than those in Wisconsin, and weighed alternatives in a manner that clearly resembled modern project planning and evaluation (Scheiber, 1969: 88-92, 355-88; 1970: 752-55).

Still other styles of legal process are suggested by the experience in Louisiana, where banking policies (Green, 1972) and transport improvement efforts (Reed, 1966) represented a middle ground between "drift and default" and antecedents of modern planning; in Georgia (Heath, 1954); and in some western states-Colorado, which early began to control irrigation, and California, which engaged in a complex ordering of economic priorities by the legislature and the courts in the period before 1890 (McCurdy, 1976; G. Nash, 1964; Bakken, 1970).

For the late nineteenth century and the Progressive era, recent studies suggest still other modes of policy making and variants of legal process. One of the most dramatic attributes of our federal system is "forum-shopping" in litigation and its functional equivalent (which may be termed "level-seeking") in efforts to influence legislation. The constitutional and legislative origins of post-Civil War federal jurisdiction are treated in the careful work of Wiecek (1969), and the crosspressures and politics of diversity jurisdiction, as well as the relevant constitutional law, in studies by Freyer $(1976,1979 a$, 1979b). The much-debated books by Robert Wiebe (1962) and Gabriel Kolko $(1963,1965)$ raise important questions about how to describe the process of lawmaking that led to industrial regulation, first by the states and later by Congress. Regional, functional, class, and even more fragmented pressure groups are identified in all these scholars' writings, but whether regulation reflected the interests of the regulated is still open to question. Whatever the correct historical model of regulation, there is potential here for differentiating types of legal process by states (or regions), which may further reveal the diversity within the system. The major companies of the insurance industry constantly exerted pressure for uniform national regulation; they repeatedly challenged state law in the courts and were caught in an incredible crossfire of "retaliatory" and "reciprocal" state laws (Keller, 1963). The movement for a child-labor law, and later for a constitutional amendment, foundered on interstate rivalries and jealousies; here reformers sought a uniform national standard, while the interests to be regulated opposed it (Wood, 1968). How privately organized professional associations, atomistic units 
within the medical profession, political parties, and courts all contributed to policy formulation in a complex legal process in the 1920s may be glimpsed from examination of the fight over the Sheppard-Towner legislation for maternity-aid grants to the states (cf. Vose, 1972: 243-74).

Another kind of typology is suggested by Friedman's highly original study (1965) of contract law in Wisconsin. Examining how the courts functioned in this area and with what effects, and how this related to the work of the legislature and to major economic interests, Friedman provided a series of "deep probes" for three different periods of time. Unfortunately, there has been no similar study of any comparable major problem in the legal process of other states. The potentialities, however, are manifest, especially if research can employ better data to conduct a more comprehensive analysis of process models in several states and over a longer period. A "macro" view of the state supreme courts is offered by Kagan and others $(1977,1978)$ in studies of institutional structure, caseload, and subject-matter distribution. These two articles provide a solid empirical basis including both quantitative data that permit comparison of state court systems and a historical narrative of judicial reform and its effects; moreover, the data are related to the literature on such topics as dissent rates in the recent record of state supreme courts (Kagan, 1978: 996 n.76). Jones's (1979) institutional analysis of state decisions granting certificates of public convenience and necessity to public utilities complements the studies of state supreme courts, but parallel investigations of other major policy innovations are also needed.

Of great influence in historical policy studies has been the three-part typology worked out by Lowi (1964), distinguishing distributive, redistributive, and regulatory laws and indicating how the politics in one area tends to differ from politics in the other two. A decade ago, I suggested the way in which Hurst's historical and normative models were relevant to Lowi's construct (Scheiber, 1970: 752-55). At about the same time Beer (1973) was working out his historical model, strongly influenced by Lowi. More recently McCormick (1979) has tried to synthesize all such work, as well as the considerable historical literature on "political culture" in the states (such as ethnocultural dimensions of voting behavior), to create a grand synthesis of the determinants of voting, the legislative process, and policy outcomes. Although this fascinating effort falls short, it provides still another framework for suggesting links 
between historic and modern federalism. ${ }^{23}$

I think the cumulative evidence in the foregoing studies is overwhelming that the working federal system was diverse; that real power was exercised in myriad ways at the state level; that substantial change occurred over time so that the synchronic mosaic of law becomes a moving kaleidoscope; and that the abstract, legalistic concept of "dual federalism" had real-life meaning, a palpable presence in both the dynamics of legal process and the substantive content of the law. ${ }^{24}$

The performance record of governmental quality within the federal system is at best mixed. Hurst's studies clearly reveal the shortsighted and fragmented nature of much state policy; as suggested earlier, however, government was not merely reactive to private pressures. Diffused real power also meant that there was duplication of effort: a wholly "rational" system of transport would perhaps have been approached more closely if so many different jurisdictions had not been pursuing competing, overlapping functions. Other areas of policy, especially banking, were similarly affected. On the other hand, we have Friedman's interesting assessment that "there is little that [state] government does in the 20th century that does not have some analogy to what government wanted to do or tried to do, on a much smaller scale, in the 19th" and that though antebellum social policy was "fragmentary in concept and local in implementation," still government's performance was impressive, given the resources at its command (1965: 149-50).

Of the transition to modern cooperative federalism, McConnell (1966) argues that devotion to the decentralizing principles of federalism allowed excessive play to particularistic local interests and to the exploitative machinations of local elites. Similarly, even social reforms or industrial controls that appear most benevolent, such as coalmining safety, foundered in the states and were attenuated in their impact by the "uniform code" technique that offered a

23 The notes to Jacob and Lipsky (1968) offer a guide to the considerable literature on behavioral variables, environmental variables, and policy outcomes; see also Friedman (1975: 148ff.).

24 Thomas Cochran (1975) offers an extremely pessimistic view of the economic impact of federalism on what he claims was a persistent retardation of American economic growth. He cites "regional enmities, numerous state governments, and local jurisdictions" as making interregional capital transfers difficult, while "localism" produced corrupt or inefficient government and also placed excessive burdens on enterprise (Ibid.: 934-35). In my own view, the more significant economic effects of localism and decentralized power probably were enclaves of economic privilege, corporate giantism, and difficulties in bringing private-sector institutions under governmental regulation (Scheiber, 1975a, 1978b). 
convenient alternative to strong national legislation (Graebner, 1976).

Performance must also be evaluated in terms of individual liberty, which, after all, is at the core of the values claimed for American federalism. Any evocation of the antebellum period as a golden age must be qualified: it was, after all, the period of slavery. Still, the era was characterized by a broadening of the suffrage for white males, significant challenge to "deference" and to established elite authority, even in the southern states, and the ascendency of ideological radicals elsewhere. On balance, however, we have to concede that conservative fondness for decentralized power has a realistic basis in American history; states' rights have worked for repressive purposes as well as nobler ones, and slavery is but the worst example (cf. Roche, 1963; Pekelis, 1950: 127).

In the period from 1865 to the New Deal, the historical evidence is again mixed. On the one hand, government gained the strength that derives from expertise, bureaucratization, funding through flexible revenue sources, and the acquisition of a wide range of new responsibilities. Despite impediments ingeniously thrown up by a conservative judiciary (cf. Paul, 1960), social-welfare concerns, industrial regulation, conservation, expanded public education, and public health made great gains in many (though certainly not all) the states (Beth, 1971: 72-138). On the other hand, there was a grotesque failure of egalitarian ideals and civil rights. It was, of course, the continued vitality of federalism that permitted the hegemony of segregationist institutions and the violence against blacks, antisyndicalism and other repressive state laws in the $1920 \mathrm{~s}$, and the horrors of the criminal process from arrest through imprisonment (see, e.g., P. Murphy, 1971). The continuation of these trends through the New Deal era and the way in which local interests were able to manipulate the ideals of federalism for conservative purposes has been ably chronicled by Patterson (1969; see also Reading, 1973) and by Selznick in his study of TVA (1966).

The model of federalism derived from history cannot, therefore, give much support to those who equate decentralization with freedom. Thus, Neumann observes that federal diffusion of power could cut both ways: the syndicalism laws of the 1920s (like antebellum slavery and postbellum Jim Crow legislation) offered evidence that liberty could be, and often was, abridged with brutal swiftness and efficiency by the constituent states (1955: 48-49, 53-54). This conclusion, which 
runs entirely counter to the conventional wisdom, is particularly alarming when one recalls that judicial review has also failed to function consistently in defense of individual liberty, especially in crises when it is needed most (see Frank, 1954). Indeed, Roche argues in his general history of civil liberties in America that the potential tyranny of face-to-face relationships in small nineteenth-century communities was at least as repressive as the restraints on freedom found in modern mass society. His view supports Neumann's claim that "federalism, as such, has nothing in it that automatically guarantees the preservation of political freedom" (1955: 531). More lately, Jesse Choper has concluded that the state and local governments are mainly a threat to, not reliable protectors of, civil liberties (1977: 1618). ${ }^{25}$

\section{THE ROLE OF THE COURTS}

Institutional structures, Friedman has written, "come out of history, culture, and tradition"; federalism is "a cluster of structures."

A structure like federalism is both a cause and an effect. It is surely an effect of the culture, especially in so far as federalism is a living organism [that is to say, not merely nominal, as with federal structure in the Soviet Union]. Federalism, however, may also be a fact; its ideas and shapes become part of the common stock of beliefs and expectations. People accept the federal system and act accordingly, because they do not find anything else really conceivable. Structure becomes, in short, custom or habit. [1975: 158]

Other commentators have made the same point historically: when policy issues were considered in the era of dual federalism "the question was never simply: should the most suitable agency of government undertake collective action to solve the problem? Always there was the second question: according to the Constitution, should the national government,

25 Choper persuasively distinguishes principled issues (personal liberties and their violation by government) from pragmatic issues (the traditional "federal question" of which level of government ought to act in a given area), and he contends that the former require federal judicial review, whereas the latter ought to be settled politically (1977: 1552-56). Like Neumann and Roche, Choper denies that the decentralization of authority under federalism is a guarantor of individual liberties and hence a value worth preserving through judicial review. Thus he would have the courts withdraw from intervention in such matters as those raised by National League of Cities. Although I agree with Choper that state and local governments have violated individual rights more consistently than has the federal government, I cannot take as sanguine a view of the federal record on civil liberties. Consider, for instance, the Alien and Sedition Acts, the suppression of antislavery mailings, the fate of free speech and press in World War I, the 1919 Red Scare, etc. It is true that the first Supreme Court decision finding federal violation of the First Amendment came only in 1965 , but that is because the Court so consistently deferred to the executive and legislative branches and failed to interpose judicial power (compare Choper, 1977: 1618-19). 
or State and local governments, undertake the action? (Shields, 1952: 109-10). Once the structure is erected, even if formal authority continues to change with constitutional interpretation, the instrumentalities of federalism "become rigidified and acquire a status of their own" in the overall political process. "They become substantive instead of merely adjectival; they become ends in themselves instead of merely means toward other ends.... and ultimately the instrumentalities enter into and become part of the psychosociological complex itself" (Livingston, 1952: 93). The interpenetration of structure and attitude infuses the dynamics of the political process, which in turn is channeled mainly through extraconstitutional structures (the federalized, statebased parties) that are themselves the product of federalism.

Although it would be an exaggeration to contend that federalism is "perhaps as much a state of mind as anything else" (Vile, quoted in Reagan, 1972: 26), attitude certainly does matter. Earlier we noted "considerations of federalism" in the contemporary political process (p. 689, supra), but such considerations were influential from the very beginnings of the Republic. What is often termed "constitutionalism"-respect, even reverence, for the federal division of power, the Supreme Court as umpire of the federal system, and the traditional values associated with localism and diffused power-tends to figure in the calculus of nearly all major domestic policy issues.

The recent literature in legal and constitutional history provides fascinating testimony about the interplay of attitude, structure, and politics, especially at points of crisis in which the courts have played a central role. In the antebellum period, for example, the controversy over slavery arose in a legal environment characterized by "two conflicting systems of law exist[ing] side by side in different sections of the country" (Morris, 1974: 1). The political system ultimately fractured under antislavery pressures more because of those legal differences than because of strains between the two levels of governance within federalism. The doctrines and established mechanisms of federalism (especially comity) shaped the debates of the $1850 \mathrm{~s}$, and ultimately, as Bestor has shown (1964), doctrinal initiatives by courts in the free states on fugitive slave questions raised intense Southern fears and became the volatile material of sectional conflict. Another legal dimension in that crisis of federalism was the enforcement of, or resistance to, "slave-catching," vividly portrayed by Stanley Campbell (1970). 
Fairman (1971) illuminates another episode in which "constitutionalism" converged with initiatives by state judges to alter the structure and doctrines of federalism. In this instance, the issues were economic ones colored by regional parochialism, intersectional hostility, and "anti-foreignism."26 State supreme courts in the postbellum years legitimated the repudiation of railroad-aid bonds by scores of municipalities on the ground that their issuance had violated the state constitution, which limited such aid to "public purpose" businesses (1971: 934-42; see also Scheiber, 1972: 392-97). When the U.S. Supreme Court ruled that it was justified by general principles of jurisprudence in overruling the interpretation given by the Iowa Supreme Court to its own state constitution, the lines of battle were drawn (Gelpcke v. Dubuque, 1 Wall. 175, 1864). The Iowa press warned of "the practical evils of consolidation" (i.e., centralized power) (Fairman, 1971: 943); a federal judge cuttingly referred to "the issue of the late Rebellion" in condemning a state judge who sought to deny the controlling authority of Gelpcke (U.S. v. Lee County, Fed. Case No. 15, 589, 1869); and there was talk of "armed resistance," "the brink of rebellion," and "insult to the State [of Iowa]," to say nothing of "compromise [of] manhood" (Fairman, 1971: 966-68). The moment of highest drama came in June 1870, when President Grant publicly declared his readiness to send troops to enforce the judgment of federal courts in Iowa or any other state, just as troops had been used to support Reconstruction in the South (Ibid.: 985).

Grant's declaration probably determined the outcome: politicians and their constituents, who felt cheated by the failure of railroads to build or operate after receiving public bond aid, backed down and accepted the effective verdict of the Supreme Court. (Another ex-general in the White House, President Eisenhower, might well have learned from Grant's example; one wonders what would have happened at Little Rock had he threatened intervention with troops at the outset of resistance by local segregationists and Governor Faubus.) What is instructive, however, is that the political configuration of the railroad bond-aid question in the 1860s and 1870s was determined by federal structure and doctrine, by the rhetorical and attitudinal links to the discredited symbols of "resistance"

26 The term "foreign" was used not only in a technical legal sense, to describe a corporation domiciled in another state, but also in the popular political rhetoric of the nineteenth century to describe outside economic interests of any sort. 
and "disunion" so soon after the Civil War, and by tension between the values of dual federalism and centralism.

As so often happens in such crises, political actors found themselves with strange bedfellows or in unfamiliar clothing. Thus notorious disunionists (Copperheads) of a few years earlier were asserting the superior authority of the federal courts in the railroad bond-aid controversy, whereas staunch Union men of the war years were suddenly champions of the cheated populace and therefore strident advocates of state interposition. The legitimacy of the Supreme Court ruling was buttressed by parallels with constitutional doctrines that supported contemporaneous Reconstruction policy; the press made frequent allusion to that paradoxical situation, and the lessons of war were effectively invoked by those who sought to quiet the conflict (Fairman, 1971: 1074-76, 1081, 1088).

Studies that focus on the role of courts in the federal legal process today have a more difficult task because the programs with which they deal have become more elaborate, often overlapping or operating at cross-purposes, and the courts themselves have generally adopted a more comprehensive definition of their role in implementing policy and shaping social change. Nevertheless, we are beginning to get elaborate inquiries into how the judiciary has functioned in the swiftly changing world of IGR and programmatic complexity. Work such as Horowitz (1977) that investigates and criticizes federal judicial intervention in community action programs brightly illuminates one corner, at least, of the labyrinthine structure of modern federalism, whatever one may think of the author's bias in favor of judicial self-restraint. Lowi's study of an Illinois community distressed by a major new federal nuclear installation, and especially his unforgettable five-page diagram of the federal-state-local lines of power and decision (1976: 812), may profitably be read together with the portrayal by Gelfand (1975) of federal-municipal relationships "in the beginning" (the 1930s), a bureaucratic world now hopelessly beyond recapture that appears, by today's standards, to be one of pristine simplicity.

Lowi's model (1976: 13) of contemporary federalism in action as a system of "mutual ignorance and mutual noninterference among all the layers," although ultimately subject to highly centralized power, is only one among many depictions of working federalism in the modern scholarly literature. Numerous "impact studies" have taught us how lawenforcement officials and state and lower federal courts 
respond to Supreme Court doctrinal leads with creative adaptation (bordering on subversion of judicial intent), outright resistance, or grudging or even zealous compliance; few areas of social science research have so well documented the complex interpenetration of attitudes and structure and the interrelationships among separation of powers, federalism, and the dynamics of informal political processes (see Becker and Feeley, 1973). Similarly, studies that focus on implementation of specific programs have indicated how difficult it is to say whether a nominally centralized program has done anything more than respond to local pressures channeled through Congress, national agencies, and the parties; or than provide "a stifling array of meaningless forms and-very important-a pot of gold . . . to be spent as the locals dictated," as Friedman has written of the Great Society's poverty programs (1977: 38).

In short, "federal" and "state and local" are not a pair of terms that run parallel to "centralized" and "diffuse." Some programs are completely "federal" (meaning that by law they are out of the jurisdiction of states and municipalities) but are, in fact, highly decentralized. The draft machinery of the Second World War, with its pattern of neighborhood draft boards, was a perfect example of this type. And some very central $[\mathrm{sic}]$ programs, like OASDI, do not require much in the way of policy and discretion. The package of Great Society programs contained examples of almost every sort. [Ibid.: 40]

Even revenue sharing, with its clearly centralized pot of gold, has been subject to further refinement that distinguishes between older styles of IGR and what one analyst (Brown, 1977) terms "interventionist federalism," which imposes conditions on structure, style, and rules of state or local government even while there are no controls over the purpose for which the funds are spent. There has also been much scholarly interest lately in federal judicial curbs upon state authority and discretion in the administration of federally funded programs-in the definitions of eligibility for aid, for example (see King v. Smith, 392 U.S. 309, 1968; Rosado v. Wyman, 397 U.S. 397, 1970)-which indicates the difficulty of separating what is truly centralized power from what is truly diffused (cf. Bloch, 1979; Mishkin, 1978).

\section{CONCLUSION}

I began this article by observing that the study of federalism is in some disarray, despite the central role it has long had in historical and legal studies. Recent historical literature has clearly helped to reorient this field in a more productive direction by contributing to our knowledge of certain crucial issues. The first is the question of how real power has correlated with the constitutional doctrines that 
comprise the shifting "map" of formal authority. Second, historical studies have given us not only a framework (or rather several) for understanding basic, qualitative changes over nearly two centuries of American federalism but also a great deal of newly developed empirical data concerning the actual behavior of government at each level in each historical epoch. Third, there is now a considerable body of welldocumented material on state policy, administration, and judge-made law that provides evidence of the diversity, reach, and impact of governmental action. Fourth, a substantial body of this historical writing accords well with contemporary social research and studies of legal process: the role of parties, the relationship between policy decisions and political behavior, the separation of powers as a working system, and the like. And finally, studies of both historical and contemporary federalism offer insights into the changing structure and operation of the intergovernmental relations, a subsystem of federalism and not a successor to it. Cutting across all these inquiries are considerations of how effectively government has performed as society has changed and the federal system along with it; how successfully federalism protects individual liberty (if it does so at all); and how residual elements of older stages of federalism-doctrines, structures, or policies-have survived in succeeding epochs, including the present.

The most important issue, of course, is whether federalism has enough enduring value to merit preservation as a matter of principle. Among commentators who are dubious, if not convinced skeptics like Riker (supra, page 664), Jesse Choper contends that no matter what the impact of federalism on governmental efficiency or other measures of performance, "the assertion that federalism was meant to protect, or does in fact, protect, individual constitutional freedoms has no solid historical or logical basis" (1977: 1611). Equally eloquent testimony for the opposite view comes from the late Martin Diamond, who regarded the notion that the Constitution "made an authoritative allocation of functions" between state and national governments as an article of faith, at the very core of American legal doctrine (1976: 192).

If there is anything whatsoever left to that federal enumeration, to that division of authority between the nation and the states under the Constitution, then it follows that some injustices and miseries are unreachable by the national government. This is deplorable with respect to the nationally unreachable injustice; but that unreachability, with respect to matters reserved to the states, is the price of the many benefits of federalism that we enjoy under our Constitution, if we still have one. [Ibid.: 193] 
Yet the question that remains is the one posed by Norman Dorsen. Even if

separation of powers and federalism are, intrinsically the instruments of neither efficiency nor effectiveness, but rather means to assure liberty . . . [still we are left with] the double problem of freedom in the context of federalism. On the one hand, the desire to enhance individual liberty and creativity, and responsive self-government; on the other, to assure that politically weak or isolated groups are not victimized by [locally dominant] interests traditionally insensitive to their plight. [1977: 70, 69]

Perhaps "it is an aspect of freedom to be able to live with a minimum of external control, and this principle seems applicable to small communities as well as individuals" (Ibid.: 68). But the question of how well freedom has been served by the doctrines, structures, and day-to-day exercise of real power in each historical epoch of American federalism gives a heightened significance to contemporary research that might otherwise be confined to relatively arid investigation of microscopic administrative problems or technical legal questions. Federalism does matter, and we can better understand why it matters by seeking to grasp its historical dimension rather than resorting to ex cathedra assertions or mere expressions of faith.

\section{REFERENCES}

ABRAHAM, Henry (1976) "Effectiveness of Governmental Operations," 426 Annals 81.

ADRIAN, Charles R. and Charles PRESS (1964) "Why Our State Governments are Sick," 24 Antioch Review 165.

ADVISORY COMMISSION ON INTERGOVERNMENTAL RELATIONS (1979) "Government UnLocked: Political Constraints on Federal Growth" [unpublished manuscript scheduled for 1980 publication].

ALARCON, Arthur L. (1979) "California Constitution and the Federal Courts," in Law and California Society: 100 Years of the State Constitution. San Diego, Calif.: The San Diego Union and the University of California, San Diego.

AMERICAN CRIMINAL LAW REVIEW (1976) "Note: State Constitutional Guarantees as Adequate State Ground: Supreme Court Review and Problems of Federalism," 13 American Criminal Law Review 737.

ANDERSON, William (1955) The Nation and the States. Minneapolis: University of Minnesota Press.

- (1960) Intergovernmental Relations in Review. Minneapolis: University of Minnesota Press.

ARONS, Stephen and Ethan KATSH (1975) "Reclaiming the Fourth Amendment in Massachusetts," 2 Civil Liberties Review 82.

BAKER, Stewart A. (1977) "Federalism and the Eleventh Amendment," 48 University of Colorado Law Review 139.

BAKKEN, Gordon M. (1970) "The Impact of the Colorado State Constitution on Rocky Mountain Constitution-Making," 47 Colorado Magazine of History 152.

BEAM, David (1979) "The Accidental Leviathan: Was the Growth of Government a Mistake?" 5 (4) Intergovernmental Perspective 12.

BEARD, Charles A. (1913) An Economic Interpretation of the Constitution. New York: Macmillan. 
BEARD, Charles A. and William BEARD (1930) The American Leviathan: The Republic in the Machine Age. New York: Macmillan.

BECKER, Theodore L. and Malcolm M. FEELEY (1973) The Impact of Supreme Court Decisions, 2d ed. New York: Oxford University Press.

BEER, Samuel (1973) "The Modernization of American Federalism," 3 Publius 75.

- (1977) "Political Overload and Federalism," 10 Polity 5.

(1978) "Federalism, Nationalism, and Democracy in America," 72 American Political Science Review 9.

BENSON, George C.S. (1965) "Trends in Intergovernmental Relations," 359 The Annals 1.

BERLE, Adolph A., Jr. (1955) "Evolving Capitalism and Political Federalism," in Macmahon (1955).

BESTOR, Arthur (1964) "The American Civil War as a Constitutional Crisis," 69 American Historical Review 327. Reprinted in L. Friedman and H. Scheiber (eds.) (1978).

BETH, Loren (1971) The Development of the American Constitution 1877-1917. New York: Harper and Row.

BICKEL, Alexander (1970) The Supreme Court and the Idea of Progress. New York: Harper and Row.

BLOCH, Frank S. (1979) "Cooperative Federalism and the Role of Litigation in the Development of Federal AFDC Eligibility Policy," 1979 Wisconsin Law Review 1.

BRAEMAN, John, Robert H. BREMNER and David BRODY (eds.) (1975) The New Deal: The State and Local Levels. Columbus, Ohio: Ohio State University Press.

BRENNAN, William (1977) "State Constitutions and the Protection of Individual Rights," 90 Harvard Law Review 489.

BRETON, Albert and Anthony SCOTT (1978) The Economic Constitution of Federal States. Toronto: University of Toronto Press.

BRODER, David S. (1974) "A New States' Rights Battle," Los Angeles Times, November 27, 1974, part ii, p. 5.

- (1978) "Canniness of the Long-Distance Runner," 241 (1) The Atlantic 35

BROWN, George D. (1977) "Beyond the New Federalism-Revenue Sharing in Perspective," 15 Harvard Journal on Legislation 1.

CAMPBELL, Alan K. (1965) "National-State-Local Systems of Government and Intergovernmental Aid," 359 The Annals 94.

CAMPBELL, Stanley W. (1970) The Slave Catchers: Enforcement of the Fugitive Slave Law, 1850-1860. Chapel Hill, N.C.: University of North Carolina Press.

CAREY, Hugh L. (1977) "Pulling Together," New York Times, Feb. 14, 1977, p. 27.

CARY, William A. (1974) "Federalism and Corporate Law: Reflections upon Delaware," 83 Yale Law Journal 663.

CHOPER, Jesse H. (1977) "The Scope of National Power Vis-a-Vis the States: The Dispensability of Judicial Review," 86 Yale Law Journal 1552.

CLARK, Jane Perry (1938) The Rise of a New Federalism. New York: Columbia University Press.

COCHRAN, Thomas C. (1975) "The Paradox of American Economic Growth," 61 Journal of American History 925.

COLEMAN, Peter (1974) Debtors and Creditors in America: Insolvency, Imprisonment for Debt, and Bankruptcy, 1607-1900. Madison, Wis.: State Historical Society of Wisconsin.

CORWIN, Edward S. (1950) "The Passing of Dual Federalism," 36 Virginia Law Review 1.

CRENSON, Matthew A. (1975) The Federal Machine: Beginnings of Bureaucracy in Jacksonian America. Baltimore: Johns Hopkins University Press.

DAVIS, Lance E. and John LEGLER (1966) "The Government in the American Economy, 1815-1902: A Quantitative Study," 26 Journal of Economic History 514.

DAVIS, Rufus (1955) "The 'Federal Principle' Reconsidered: Part I," 1 Australian Journal of Politics and History 59. (1978) The Federal Principle: A Journey Through Time in Quest of Meaning. Berkeley, Calif.: University of California Press.

DERTHICK, Martha (1970) The Influence of Federal Grants: Public Assistance in Massachusetts. Cambridge, Mass: Harvard University Press. 
(1974) Between State and Nation: Regional Organizations of the U.S. Washington, D.C.: Brookings Institution.

DIAMOND, Martin (1961) "What the Framers Meant by Federalism," in Robert A. Goldwin (ed.) A Nation of States: Essays on the American Federal System. Chicago: Rand McNally.

(1964) "On the Relationship of Federalism and Decentralization," in Daniel Elazar (ed.) Cooperation and Conflict: Readings in American Federalism. Itasca, Ill.: F.E. Peacock.

(1976) "The Forgotten Doctrine of Enumerated Powers," 6 Publius 187.

DIAMOND, Stephen (1979) "Legal Realism and Historical Method: J. Willard Hurst and American Legal History," 77 Michigan Law Review 784.

DIKSHIT, Ramesh Dutta (1975) The Political Geography of Federalism: An Inquiry into Origins and Stability. New York: John Wiley \& Sons.

DORSEN, Norman (1977) "Separation of Powers and Federalism," 41 Albany Law Review 53.

DUCHACEK, Ivo D. (1977) "Antagonistic Cooperation: Territorial and Ethnic Communities," 7 Publius 3.

EARLE, Valerie (ed.) (1968) Federalism: Infinite Variety in Theory and Practice. Itasca, Ill.: F.E. Peacock.

EASTON, David (1969) "The New Revolution in Political Science," 63 American Political Science Review 1051.

ELAZAR, Daniel (1962) The American Partnership: Intergovernmental Cooperation in the Nineteenth Century. Chicago: University of Chicago Press.

- (1965) "The Shaping of Intergovernmental Relations in the Twentieth Century," 359 The Annals 10.

(1966) American Federalism: A View from the States. New York: Thomas Y. Crowell.

(1972) Book review, 2 Publius 147.

(1975) "Urbanism and Federalism," 5 Publius 15.

- (1976) "Federalism vs. Decentralization: The Drift from Authenticity," 6 Publius 9.

FAIRMAN, Charles (1971) Reconstruction and Reunion, 1864-88, Part One. New York: Macmillan [Oliver Wendell Holmes Devise History of the Supreme Court of the United States, Vol. VI].

FARNHAM, Wallace D. (1963) "The Weakened Spring of Government': A Study in Nineteenth-Century American History," 68 American Historical Review 662 .

FARRAND, Max (1937) 3 Records of the Federal Convention of 1787 (rev. ed.). New Haven, Conn.: Yale University Press.

THE FEDERALIST (Jacob Cooke ed.) (1961) Middleton, Conn.: Wesleyan University Press.

FESLER, James W. (1949) Area and Administration. University, Ala.: University of Alabama Press.

(1965) "Understanding of Decentralization," 27 Journal of Politics 536.

FTNE, Sidney (1956) Laissez Faire and the General-Welfare State: A Study of Conflict in American Thought, 1865-1901. Ann Arbor: University of Michigan Press.

FISS, Owen M. (1977) "Dombrowski," 86 Yale Law Journal 1103.

FLAHERTY, David H. (ed.) (1969) Essays in the History of Early American Law. Chapel Hill, N.C.: University of North Carolina Press.

FLEMING, Donald, and Bernard BAILYN (eds.) (1972) Law in American History. Boston: Little, Brown.

FRANK, John P. (1954) "Judicial Review and Basic Liberties," in Lawrence Friedman and Harry Scheiber (eds.) American Law and the Constitutional Order. Cambridge, Mass.: Harvard University Press, 1978.

FREYER, Tony (1976) "Negotiable Instruments and the Federal Courts in Antebellum American Business," 50 Business History Review 435. (1979a) "The Federal Courts, Localism, and the National Economy, 18651900," 53 Business History Review 343. (1979b) Forums of Order: The Federal Courts and Business in American History. Greenwich, Conn.: JAI Press.

FRIEDMAN, Lawrence M. (1965) Contract Law in America: A Social and Economic Case Study. Madison, Wis.: University of Wisconsin Press.

_ (1969) "Legal Culture and Social Development," 4 Law \& Society Review 29.

(1973) A History of American Law. New York: Simon and Schuster. 
(1975) The Legal System: A Social Science Perspective. New York: Russell Sage Foundation.

(1977) "The Social and Political Context of the War on Poverty: An Overview," in A Decade of Federal Antipoverty Programs. Madison, Wis.: University of Wisconsin Institute for Research on Poverty.

FRIEDMAN, Lawrence M. and Jack Ladinsky (1967) "Social Change and the Law of Industrial Accidents," 67 Columbia Law Review 50.

FRIEDMAN, Lawrence M. and Robert V. PERCIVAL (1980) The Roots of Justice: Crime and Punishment in Alameda County, California, 1870-1910. Chapel Hill, N.C.: University of North Carolina Press [in press].

FRIEDMAN, Lawrence M. and Harry N. SCHEIBER (eds.) (1978) American Law and the Constitutional Order: Historical Perspectives. Cambridge, Mass.: Harvard University Press.

FRIEDRICH, Carl (1968) Trends of Federalism in Theory and Practice. New York: Praeger.

FRIENDLY, Henry (1977) "Federalism: A Foreword," 86 Yale Law Journal 1019.

GELFAND, Mark I. (1975) A Nation of Cities: The Federal Government and Urban Life in America. New York: Oxford University Press.

GILBERT, Charles E. (1976) "The Shaping of Public Policy," 426 The Annals 116.

GILBERT, Charles E. and David G. SMITH (1968) "The Modernization of American Federalism," in Murray M. Stedman (ed.) Modernizing American Government. Englewood Cliffs, N.J.: Prentice-Hall.

GOODRICH, Carter (1968) "State In, State Out: A Pattern of Development Policy," 2 Journal of Economic Issues 365.

- (1970) "Internal Improvements Reconsidered," 30 Journal of Economic History 295.

GOODWIN, Richard (1967) "The Shape of American Politics," Fred Krinsky (ed.) Democracy and Complexity. Beverly Hills: Glencoe Press [Reprinted from 43(6) Commentary 25 (June 1967)].

GORDON, George J. (1978) Public Administration in America. New York: St. Martin's Press.

GORDON, Robert W. (1975) "Introduction: J. Willard Hurst and the Common Law Tradition in American Historiography," 10 Law \& Society Review 9.

GRAEBNER, William (1976) Coal-Mining Safety in the Progressive Period: The Political Economy of Reform. Lexington, Ky.: University of Kentucky Press.

GRAVES, Thomas J. (1974) "IGR and the Executive Branch: The New Federalism," 416 The Annals 40.

GRAVES, W. Brooke (1964) American Intergovernmental Relations: Their Origins, Historical Development, and Current Status. New York: Scribner's.

GREEN, George (1972) Finance and Economic Development in the Old South Louisiana Banking 1804-1861. Stanford, Calif.: Stanford University Press.

GROB, Gerald (1976) "The Political System and Social Policy in the 19th Century," 58 Mid-America 5. (1979) "Reflections on the History of Social Policy in America," 7 Reviews in American History 293.

GRODZINS, Morton (1960) "The Federal System," in Goals for Americans (Report of the President's Commission on National Goals). Englewood Cliffs, N.J.: Prentice-Hall.

(1963) "Centralization and Decentralization," in Robert A. Goldwin (ed.) A Nation of States. Chicago: Rand McNally.

- (1966) The American System: A New View of Government in the United States, (Daniel J. Elazar, ed.). Chicago: Rand McNally.

HAAR, Charles M. (1975) Between the Idea and the Reality: A Study in the Origin, Fate, and Legacy of the Model Cities Program. Boston: Little, Brown.

HALL, Kermit L. (1975) "The Civil War Era as a Crucible for Nationalizing the Lower Federal Courts," 7 Prologue 177.

HARPER'S MAGAZINE (1965) "A Professional Radical Moves in on Rochester: Conversations with Saul Alinsky, Part II," 231 Harper's Magazine 52.

HART, Henry M., Jr. (1955) "The Relations between State and Federal Law," in Macmahon (1955).

HARVARD CIVIL RIGHTS-CIVIL LIBERTIES LAW REVIEW (1973) "Project Report: Toward an Activist Role for State Bills of Rights," 8 Harvard Civil Rights-Civil Liberties Law Review 271. 
HEATH, Milton (1954) Constuctive Liberalism: The Role of the State in the Economic Development of Georgia to 1860. Cambridge, Mass.: Harvard University Press.

HIGHAM, John (1970) Writing American History: Essays on Modern Scholarship. Bloomington, Ind.: Indiana University Press.

HOLT, Wythe (1974) "Now and Then: The Uncertain State of NineteenthCentury American Legal History," 7 Indiana Law Review 615.

HOROWITZ, Donald L. (1977) The Courts and Social Policy. Washington, D.C.: Brookings Institution.

HORWITZ, Morton (1977) The Transformation of American Law, 1780-1860. Cambridge, Mass.: Harvard University Press.

HOWARD, A.E. Dick (1976) "State Courts and Constitutional Rights in the Day of the Burger Court," 62 Virginia Law Review 873.

HURST, J. Willard (1956) Law and the Conditions of Freedom in the 19th Century United States. Madison, Wis.: University of Wisconsin Press.

(1960) Law and Social Process in United States History. Ann Arbor, Mich.: University of Michigan Law School.

(1964) Law and Economic Growth: The Legal History of the Lumber Industry in Wisconsin, 1836-1915. Cambridge, Mass.: Harvard University Press.

- (1970) The Legitimacy of the Business Corporation in the Law of the United States. Charlottesville, Va.: University Press of Virginia. (1977) Law and Social Order in the United States. Ithaca, N.Y.: Cornell University Press.

HYMAN, Harold (1973) A More Perfect Union: The Impact of the Civil War and Reconstruction on the Constitution. New York: Knopf.

JACOB, Herbert and Michael LIPSKY (1968) "Outputs, Structure, and Power: An Assessment of Changes in the Study of State and Local Politics," in Richard I. Hofferbert and Ira Sharkansky (eds.) State and Urban Politics. Boston: Little, Brown, 1971.

JASKIERNIA, J. (1979) "Model Prawno-Ustrojowy I Model Behawiorystyczny a Teorie Rozwoju Federalismu w USA" (with English summary), Prace $z$ Nauk Politycynych, z. 12.

JEAN, Charlie (1978) "North vs. South: Second War between the States," 5(4) Southern Exchange 6.

JENSEN, Merrill (1950) The New Nation: A History of the United States during the Confederation, 1781-1789. New York: Knopf.

JENSEN, Vernon H. (1950) Heritage of Conflict: Labor Relations in the Nonferrous Metals Industry up to 1930. Ithaca, N.Y.: Cornell University Press.

JOHANSEN, R.B. (1977) "The New Federalism: Toward a Principled Interpretation of the State Constitution," 29 Stanford Law Review 297.

JONES, G.W. (1974) "Intergovernmental Relations in Britain," 416 The Annals 181.

JONES, William K. (1979) "Origins of the Certificate of Public Convenience and Necessity: Developments in the States, 1870-1920," 79 Columbia Law Review 426.

KAGAN, Robert A., Bliss CARTWRIGHT, Lawrence M. FRIEDMAN and Stanton WHEELER (1977) "The Business of State Supreme Courts, 18701970," 30 Stanford Law Review 121.

- (1978) "The Evolution of State Supreme Courts," 76 Michigan Law Review 961.

KELLER, Morton (1963) The Life Insurance Enterprise, 1885-1910. Cambridge, Mass.: Harvard University Press.

(1977) Affairs of State: Public Life in Late Nineteenth Century America. Cambridge, Mass.: Harvard University Press.

KOLKO, Gabriel (1963) The Triumph of Conservatism. New York: Free Press. (1965) Railroads and Regulation, 1877-1915. Princeton, N.J. Princeton University Press.

KURLAND, Philip B. (1968) "The Impotence of Reticence," 1968 Duke Law Journal 619

(1970) Politics, the Constitution, and the Warren Court. Chicago: University of Chicago Press.

(1978) Watergate and the Constitution. Chicago: University of Chicago Press.

KURTZ, Paul M. (1976) "Nineteenth Century Anti-Entrepreneurial Nuisance Injunctions: Avoiding the Chancellor," 17 William \& Mary Law Review 621. 
KUTLER, Stanley (1971) Privilege and Creative Destruction: The Charles River Bridge Case. Philadelphia: Lippincott.

LAMM, Richard D. (1978) "Some Reflections on the Balkanization of America" [address at Vail, Colorado, August 18, unpublished].

LANDAU, Martin (1969) "Baker v. Carr and the Ghost of Federalism," in Charles Cnudde and D.E. Neubauer (eds). Empirical Democratic Theory Chicago: Markham.

LASKI, Harold (1939) "The Obsolescence of Federalism," 98 New Republic 367.

LAUER, T.E. (1963) "The Common Law Back Background of the Riparian Doctrine," 28 Missouri Law Review 69.

- (1970) "Reflections on Riparianism," 35 Missouri Law Review 1.

LEACH, Richard H. (1970) American Federalism. New York: Norton.

LEVINSON, Sanford V. (1974) "New Perspectives on the Reconstruction Court," 26 Stanford Law Review 461.

LEVY, Leonard W. (1954) The Law of the Commonwealth and Chief Justice Shaw Cambridge, Mass.: Harvard University Press.

LIEBER, Harvey (1975) Federalism and Clean Waters: The 1972 Water Pollution Control Act. Lexington, Mass.: D.C. Heath.

LINDBLOM, Charles (1968) The Policy Making Process. Englewood Cliffs, N.J.: Prentice Hall

LIVINGSTON, W.S. (1952) "A Note on the Nature of Federalism," 67 Political Science Quarterly 81.

LLEWELYN, Karl (1934) "The Constitution as an Institution," 34 Columbia Law Review 1.

LOWI, Theodore J. (1964) "American Business, Public Policy, Case-Studies, and Political Theory," 16 World Politics 677.

- (1967) "Party, Policy, and Constitution in America," in. W.N. Chambers and W.D. Burnham (eds.). The American Party Systems: Stages of Political Development. New York: Oxford University Press. (1969) The End of Liberalism. New York: Norton.

LOWI, Theodore J. and Benjamin GINSBERG (1976) Poliside. New York: Macmillan.

LOWI, Theodore and Alan STONE (eds.) (1978) Nationalizing Government: Public Policies in America. Beverly Hills, Calif.: Sage Publications.

LYONS, Thomas (1975) The Supreme Court and Individual Rights. Menlo Park, Calif: Addison-Wesley.

MAASS, Arthur (ed.) (1959) Area and Power. Glencoe, Ill.: Free Press.

MACMAHON, Arthur W. (1955) Federalism: Mature and Emergent. New York: Columbia University Press.

- (1972) Administering Federalism in a Democracy. New York: Oxford University Press.

MAGRATH, Peter C. (1968) "The Supreme Court and a National Constitution," in Murray M. Stedman (ed.) Modernizing American Government. Englewood Cliffs, N.J. Prentice-Hall.

MANN, W. Howard (1963) "The Marshall Court: Nationalization of Private Rights and Personal Liberty from the Authority of the Commerce Clause," 38 Indiana Law Journal 117.

MARTTN, Roscoe (1965) The Cities and the Federal System. New York: Atherton.

MASON, Alpheus T. (1968) "Federalism: Historic Questions and Contemporary Meanings-The Role of the Court," in Earle (1968).

- (1969) "Judicial Activism, Old and New," 55 Virginia Law Review 385.

MATHEWS, Joseph W., Jr. (1970) "Note: State Taxation of Interstate Business-Looking Toward Federal-State Cooperation," 23 Vanderbilt Law Review 1317.

MAXWELL, James A. and J. Richard ARONSON (1977) Financing State and Local Governments (3d ed.). Washington, D.C.: Brookings Institution.

McCLOSKEY, Robert G. (ed.) (1957) Essays in Constitutional Law. New York: Knopf.

- (1972) The Modern Supreme Court. Cambridge, Mass.: Harvard University Press.

McCONNELL, Grant (1966) Private Power and American Democracy. New York: Knopf.

McCORMICK, Richard L. (1979) "The Party Period and Public Policy: An Exploratory Hypothesis," 66 Journal of American History 279.

MCCURDY, Charles W. (1975) "Justice Field and the Jurisprudence of Government-Business Relations: Some Parameters of Laissez Faire 
Constitutionalism, 1863-1897," 61 Journal of American History 970. Reprinted in Friedman and Scheiber (eds.) (1978).

(1976) "Stephen J. Field and Public Land Law Development in California, 1850-1866: A Case Study of Judicial Resource Allocation in 19thCentury America," 10 Law \& Society Review 235.

- (1978) "American Law and the Marketing Structure of the Large Corporation, 1875-1890," 38 Journal of Economic History 631.

(1979) "The Knight Sugar Decision of 1895 and the Modernization of American Corporation Law, 1869-1903," 53 Business History Review 304.

MERRIAM, Robert (1965) "American Federalism: A Paradox of Promise and Performance," in American Federalism: Toward A More Effective Partnership. Washington, D.C.: U.S. Advisory Commission on Intergovernmental Relations.

MICHELMAN, Frank I. (1977) "States' Rights and States' Roles: Permutations of 'Sovereignty' in National League of Cities v. Usery," 86 Yale Law Journal 1165.

MLIBAND, Ralph (1969) The State in Capitalist Society. New York: Basic Books.

MHLER, Arthur S. (1976a) "The Court Turns Back the Clock," 40(10) The Progressive 22 (Oct.).

- (1976b) The Modern Corporate State: Private Governments and the American Constitution. Westport, Conn.: Greenwood Press.

MILLER, Arthur S. and Alan W. SCHEFLIN (1967) "The Power of the Supreme Court in the Age of the Positive State," 1967 Duke Law Journal 522.

MHLLER, George H. (1971) Railroads and the Granger Laws. Madison, Wis.: University of Wisconsin Press.

MISHKIN, Paul J. (1978) "Federal Courts as State Reformers," 35 Washington and Lee Law Review 949.

MORRIS, Thomas D. (1974) Free Men All: The Personal Liberty Laws of the North, 1780-1861. Baltimore: Johns Hopkins University Press.

MOSHER, Frederick C. (1968) Democracy and the Public Service. New York: Oxford University Press.

MOSK, Stanley (1978) "In the Future Will State High Courts Guard Our Individual Rights?" Los Angeles Times, Jan. 1, pt. vii, p. 5.

MURPHY, Earl Finbar (1964) "The Jurisprudence of Legal History: Willard Hurst as Legal Historian," 39 New York University Law Review 900.

(1971) Man and His Environment: Law. New York: Harper and Row.

MURPHY, Paul L. (1971) The Constitution in Crisis Times, 1918-1969. New York: Harper and Row.

NASH, A.E. Keir (1970) "Fairness and Formalism in the Trials of Blacks in the State Supreme Courts of the Old South," 56 Virginia Law Review 64.

NASH, Gerald D. (1964) State Government and Economic Development: A History of Administrative Policies in California. Berkeley, Calif.: Institute of Governmental Studies, University of California.

NELSON, William E. (1974) "The Impact of the Antislavery Movement upon Styles of Judicial Reasoning," 87 Harvard Law Review 513.

- (1975) Americanization of the Common Law: The Impact of Legal Change on Massachusetts Society, 1760-1830. Cambridge, Mass.: Harvard University Press.

(1976) "Officeholding and Powerwielding: An Analysis of the Relationship between Structure and Style in American Administrative History," 10 Law \& Society Review 187.

NEUMANN, Franz L. (1955) "Federalism and Freedom: A Critique," in Macmahon (1955).

NEWMAN, Frank (1979) "The Constitution and Ethnic Pluralism," in Law and California Society: 100 Years of the State Constitution. San Diego, Calif.: The San Diego Union and the University of California, San Diego.

NICHOLS, Roy F. (1963) American Leviathan. New York: Harper and Row [originally published under the title Blueprints for Leviathan: American Style. New York: Atheneum, 1963].

OATES, Wallace E. (ed.) (1977) The Political Economy of Fiscal Federalism Lexington, Mass.: D. C. Heath.

ORLANS, Harold (1971) "Comment," in H.S. Perloff (ed.) The Future of the United States Government: Toward the Year 2000. New York: Braziller.

PAINE, Lynda Sharp (1978) "Instrumentalism v. Formalism: Dissolving the Dichotomy," 1978 Wisconsin Law Review 997. 
PALUDAN, Phillip S. (1975) A Covenant with Death: The Constitution, Law, and Equality in the Civil War Era. Urbana, Ill.: University of Illinois Press.

PATTERSON, James (1969) The New Deal and the States: Federalism in Transition. Princeton, N.J.: Princeton University Press.

PAUL, Arnold M. (1960) Conservative Crisis and the Rule of Law: Attitudes of Bar and Bench, 1887-1895. Ithaca, N.Y.: Cornell University Press.

PEKELIS, Alexander H. (1950) Law and Social Action: Selected Essays (Milton Konvitz ed.). Ithaca, N.Y.: Cornell University Press.

PERLOFF, Harvey S. (ed.) (1971) The Future of the United States Government: Toward the Year 2000. New York: Braziller.

PHILLIPS, Kevin (1978) "The Balkanization of America," 256 (1536) Harper's 37 (May).

PUBLIC INTEREST RESEARCH GROUP (1979) Bidding for Business: Corporate Auctions and the 50 Disunited States. Washington, D.C.: PIRG [mimeo].

PUBLIUS (1977) Symposium: "Federalism and Ethnicity," 7(4) Publius 1.

READING, Don C. (1973) "New Deal Activity and the States, 1933 to 1939," 33 Journal of Economic History 792.

REAGAN, Michael D. (1972) The New Federalism. New York: Oxford University Press.

REED, Merle (1966) New Orleans and the Railroads: The Struggle for Commercial Empire, 1830-1860. Baton Rouge: Louisiana State University Press.

REICH, Charles A. (1970) The Greening of America. New York: Random House.

REZNICK, Scott M. (1978) "Empiricism and the Principle of Conditions in the Evolution of the Police Power: A Model for Definitional Scrutiny," 1978 Washington University Law Quarterly 1.

RIKER, William H. (1964) Federalism: Origin, Operation, Significance. Boston: Little, Brown. (1965) Democracy in the United States (2d ed.). New York: Macmillan. (1969) "Six Books in Search of a Subject-or Does Federalism Exist and Does It Matter?" 2 Comparative Politics 135.

ROCHE, John P. (1968) The Quest for the Dream: The Development of Civil Rights and Human Relations in America. Chicago: Quadrangle.

SALISBURY, Robert H. (1968) "The Analysis of Public Policy: A Search for Theory and Roles," in Austin Ranney (ed.) Political Science and Public Policy. Chicago: Markham.

SCHEIBER, Harry N. (1969) Ohio Canal Era: A Case Study of Government and the Economy, 1820-1861. Athens, Ohio: Ohio University Press.

(1970) "At the Borderland of Law and Economic History: The Contributions of Willard Hurst," 75 American Historical Review 744.

- (1971) "Government and the Economy: Studies of the 'Commonwealth' Policy in 19th-Century America," 3 Journal of Interdisciplinary History 135 (1972) "The Road to Munn: Eminent Domain and the Concept of Public Purpose in the State Courts," in D. Fleming and B. Bailyn (eds.) Law in American History. Boston: Little, Brown.

(1975a) "Federalism and the American Economic Order, 1789-1910," 10 Law \& Society Review 57.

(1975b) "Instrumentalism and Property Rights," 1975 Wisconsin Law Review 1 .

(1977) "Back to 'The Legal Mind'? Doctrinal Analysis and the History of Law," 5 Reviews in American History 458.

- (1978a) "American Federalism and the Diffusion of Power," 9 University of Toledo Law Review 619.

(1978b) "Law and American Agricultural Development," 52 Agricultural History 439.

- (1980) "U.S. Federalism" [Paper for XVe Congres International des Sciences Historiques, to appear in Actes of the Congress. Expanded version to appear in the Polish journal of legal history, Czasopismo Prawno-Historyczne].

SCHEIBER, Harry N. and Charles W. MCCURDY (1975) "Eminent-Domain Law and Western Agriculture," 49 Agricultural History 112.

SELVIN, Molly (1980) "The Public Trust Doctrine in American Law and Public Policy," 1980 Wisconsin Law Review (forthcoming).

SELZNICK, Philip (1966) TVA and the Grass Roots. New York: Harper \& Row [originally published in 1949]. 
SHARKANSKY, Ira (1972) The Maligned States: Policy Accomplishments, Problems, and Opportunities. New York: McGraw-Hill.

- (1975) The United States: A Study of a Developing Country. New York: David McKay.

SHIELDS, Currin V. (1952) "The American Tradition of Empirical Collectivism," 46 American Political Science Review 109.

STEIN, Michael B. (1968) "Federal Political Systems and Federal Societies," 20 World Politics 721.

STEVENSON, Adlai (1950) "Reorganization from the State Point of View," 10 Public Administration Review I.

STRONG, Frank R. (1976) "Court vs. Constitution: Disparate Distortions of the Indirect Limitations in the American Constitutional Framework," 54 North Carolina Law Review 125.

SUNDQUIST, James L. (1968) Politics and Policy: The Eisenhower, Kennedy, and Johnson Years. Washington, D.C.: Brookings Institution.

SUNDQUIST, James L. with David W. DAVIS (1969) Making Federalism Work. Washington, D.C.: Brookings Institution.

TARLTON, Charles D. (1965) "Symmetry and Asymmetry as Elements of Federalism: A Theoretical Speculation," 27 Journal of Politics 861.

TRESCOTT, Paul B. (1955) "Federal-State Financial Relations, 1790-1860," 15 Journal of Economic History 227.

- (1966) "Federal Government Receipts and Expenditures, 1861-1875," 26 Journal of Economic History 206.

TRIBE, Laurence H. (1977) "Unraveling National League of Cities: The New Federalism and Affirmative Rights to Essential Government Services," 90 Harvard Law Review 1065.

(1978) American Constitutional Law. Mineola, N.Y.: Foundation Press.

TRUMAN, David B. (1955) "Federalism and the Party System," in Macmahon (1955).

TUSHNET, Mark (1975) "The American Law of Slavery, 1810-1860," 10 Law \& Society Review 119.

VAN RIPER, Paul P. (1958) History of the United States Civil Service. Evanston, Ill:: Row \& Peterson.

VAN RIPER, Paul P. and Harry N. SCHEIBER (1959) "The Confederate Civil Service," 25 Journal of Southern History 448.

VAN RIPER, Paul P. and Keith SUTHERLAND (1965) "The Northern Civil Service, 1861-1865," 11 Civil War History 351.

VOSE, Clement E. (1972) Constitutional Change: Amendment Politics and Supreme Court Litigation Since 1900. Lexington, Mass.: D. C. Heath.

WALKER, David (1974) "How Fares Federalism in the Mid-Seventies?" 416 The Annals 17.

- (1977) "The Changing Pattern of Assistance to State and Local Governments," in H.G. Frederickson and G.R. Wise (eds.) Public Administration and Public Policy. Lexington, Mass.: D. C. Heath. (1978) "A New Intergovernmental System in 1977," 8 Publius 101.

WALSTON, Roderick (1979) "Reborn Federalism in Western Water Law: The New Melones Dam Decision," 30 Hastings Law Journal 1645.

WECHSLER, Herbert (1955) "The Political Safeguards of Federalism: The Role of the States in the Composition and Selection of the National Government," in Macmahon (1955).

- (1959) "Toward Neutral Principles of Constitutional Law," 73 Harvard Law Review 1. Reprinted in Friedman and Scheiber (eds.) (1978).

WHEARE, K.C. (1963) Federal Government (4th ed.). London: Oxford University Press.

WHITE, G. Edward (1971) "The Appellate Opinion as Historical Source Material," 2 Journal of Interdisciplinary History 491.

WHITE, Leonard D. (1948) The Federalists: A Study in Administrative History, 1789-1801. New York: Free Press.

WICKWAR, William H. (1970) The Political Theory of Local Government. Columbia, S.C.: University of South Carolina Press.

WIEBE, Robert (1962) Businessmen and Reform: A Study of the Progressive Movement. Cambridge, Mass.: Harvard University Press.

WIECECK, William M. (1969) "The Reconstruction of Federal Judicial Power, 1863-1876," 13 American Journal of Legal History 333. Reprinted in L. Friedman and H. Scheiber (eds.) (1978).

WLLAVSKY, Aaron (ed.) (1967) American Federalism in Perspective. Boston: Little, Brown. 
WILLBERN, York (1959) "The States as Components in an Areal Division of Powers," in Arthur Maass (ed.) Area and Power. Glencoe, Ill.: Free Press.

WILSON, Leonard U. (1977) State Strategies for Multistate Organizations (State Planning Series, Vol. 8). Washington, D.C.: Council of State Planning Agencies, An Affiliate of the National Governors' Association.

WOOD, Stephen B. (1968) Constitutional Politics in the Progressive Era: Child Labor and the Law. Chicago: University of Chicago Press.

WOODROW WILSON INTERNATIONAL CENTER (1973) The New Federalism: A Conference. Washington, D.C.: WWIC.

WRIGHT, Deil (1974) "Intergovernmental Relations: An Analytical Overview," 416 The Annals 1.

(1975) "Revenue Sharing and Structural Features of American Federalism," 419 The Annals 100.

(1978) Understanding Intergovernmental Relations. North Scituate, Mass.: Duxbury Press.

WRIGHT, James E. (1974) The Politics of Populism: Dissent in Colorado. New Haven, Conn.: Yale University Press.

YOUNG, Crawford (1976) The Politics of Cultural Pluralism. Madison, Wis.: University of Wisconsin Press.

ZAINALDIN, Jamil S. (1979) "Emergence of a Modern American Family Law: Child Custody, Adoption and the Courts, 1796-1851," 73 Northwestern University Law Review 1038.

ZAINALDIN, Jamil S. and Peter L. TYOR (1979) "Asylum and Society: An Approach to Institutional Change," 13 Journal of Social History 23. 